\title{
Tephrochronology of the southernmost Andean Southern Volcanic Zone, Chile
}

\author{
D. J. Weller ${ }^{1}$ - C. G. Miranda ${ }^{2}$ P. I. Moreno ${ }^{2} \cdot$ R. Villa-Martínez ${ }^{3}$ - C. R. Stern ${ }^{1}$
}

Received: 30 June 2015 / Accepted: 21 November 2015 /Published online: 3 December 2015

(C) Springer-Verlag Berlin Heidelberg 2015

\begin{abstract}
Correlations among and identification of the source volcanoes for over 60 Late Glacial and Holocene tephras preserved in eight lacustrine sediment cores taken from small lakes near Coyhaique, Chile $\left(46^{\circ} \mathrm{S}\right)$, were made based on the stratigraphic position of the tephra in the cores, lithostratigraphic data (tephra layer thickness and grain size), and tephra petrochemistry (glass color and morphology, phenocryst phases, and bulk-tephra trace element contents determined by ICP-MS). The cores preserve a record of explosive eruptions, since $\sim 17,800$ calibrated years before present (cal years BP), of the volcanoes of the southernmost Andean Southern Volcanic Zone (SSVZ). The suggested source volcanoes for 55 of these tephras include Hudson (32 events), Mentolat (10 events), and either Macá or Cay or some of the many minor monogenetic eruptive centers (MECs; 13 events) in the area. Only four of these eruptions had been previously identified in tephra outcrops in the region, indicating the value of lake cores for identifying smaller eruptions in tephrochronologic studies. The tephra records preserved in these lake cores, combined with those in marine cores, which
\end{abstract}

Editorial responsibility: M.L. Coombs

Electronic supplementary material The online version of this article (doi:10.1007/s00445-015-0991-2) contains supplementary material, which is available to authorized users.

C. R. Stern

Charles.Stern@colorado.edu

1 Department Geological Sciences, University of Colorado, Boulder, CO 80309-0399, USA

2 Instituto de Ecología y Biodiversidad, Departamento de Ciencias Ecológicas, Universidad de Chile, Casilla 653, Santiago, Chile

3 Gaia-Antartica, Universidad de Magallanes, Avenida Bulnes 01890, Punta Arenas, Chile extend these records back to 20,000 cal years BP, prior to the Last Glacial Maximum, suggest that no significant temporal change in the frequency of explosive eruptions was associated with deglaciation. Over this time period, Hudson volcano, one of the largest and longest lived volcanoes in the Southern Andes, has had $>55$ eruptions (four of them were very large) and has produced $>45 \mathrm{~km}^{3}$ of pyroclastic material, making it also one of the most active volcanoes in the SVZ in terms of both frequency and volume of explosive eruptions.

Keywords Andean volcanism · Tephra · Tephrochronology · Hudson volcano $\cdot$ Chile

\section{Introduction}

The southernmost portion of the Andean Southern Volcanic Zone consists of the five large volcanic centers: Melimoyu, Mentolat, Macá, Cay, and Hudson (Fig. 1; Stern 2004; Völker et al. 2011) as well as numerous small monogenetic eruptive centers (MECs) located either along the Liquiñe-Ofqui Fault System (LOFS) or surrounding the larger volcanoes (LópezEscobar et al. 1995; D’Orazio et al. 2003; Gutiérrez et al. 2005; Vargas et al. 2013). The Holocene tephrochronology of this region has been studied from outcrops to the east and southeast of the major volcanic centers (Naranjo and Stern 1998, 2004; Mella et al. 2012); from sediment cores taken in bogs and lakes located to the east (de Porras et al. 2012; Stern et al. 2015a), the southeast (Markgraf et al. 2007; Elbert et al. 2013; Stern et al. 2015b), and the west (Haberle and Lumley 1998); as well as in some Pacific Ocean marine cores (Siani et al. 2010, 2013; Carel et al. 2011). These previous studies were limited by the lack of long cores from the southeast of the arc, which, due to the prevailing wind patterns, is the location most favorable for preserving airborne eruptive products. 


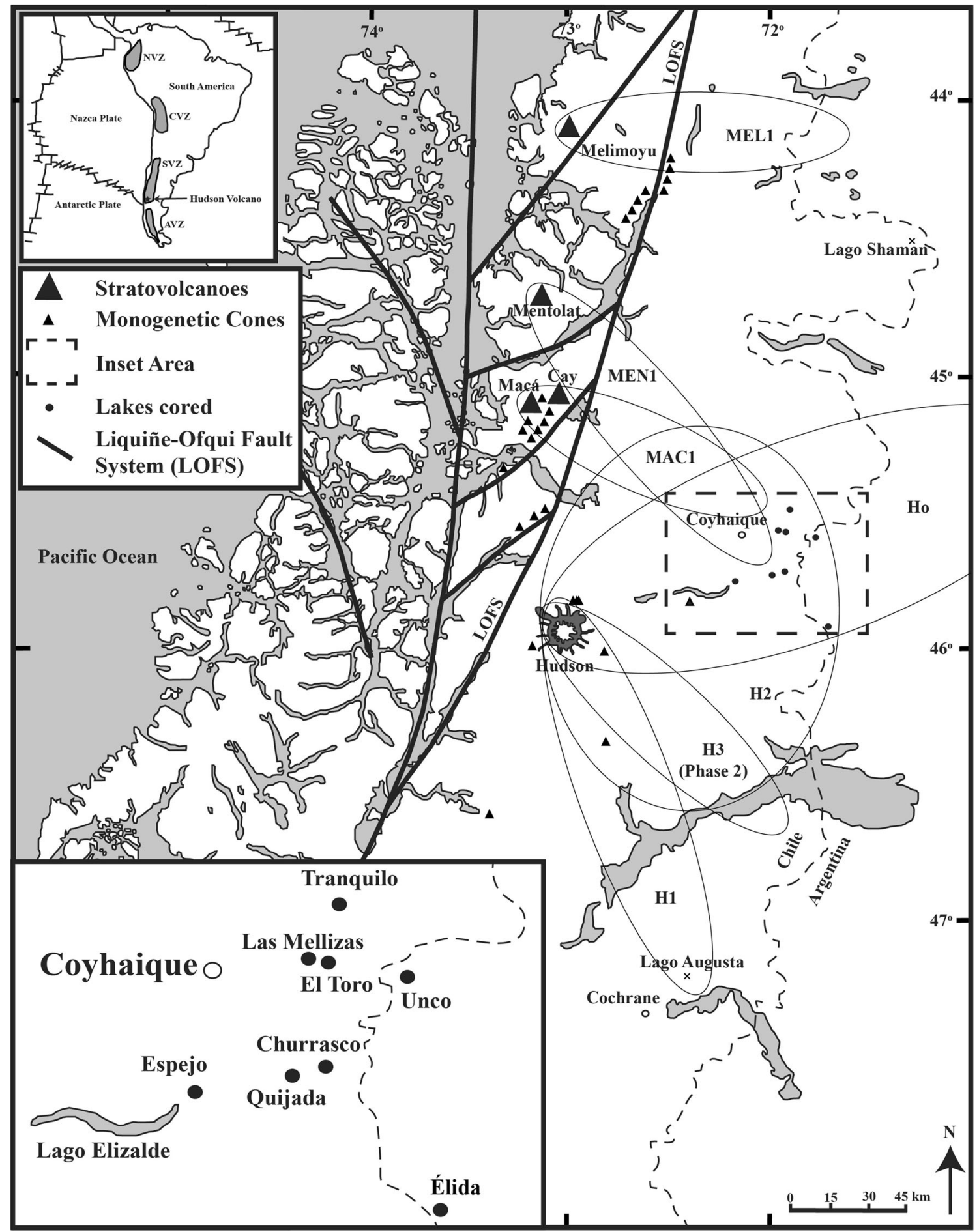

Fig. 1 Map of the southernmost portion of the Andean SVZ showing the location of the major volcanoes and some of the minor monogenetic eruptive centers (MECs) along the Liquiñe-Ofqui Fault System (LOFS) and surrounding Hudson, Macá, and Cay (Gutiérrez et al. 2005; Vargas et al. 2013). The dashed box shows the area of the inset map locating the lakes near Coyhaique from which tephra-bearing cores were obtained for this study. Also indicated are the locations of the other lakes $(x \mathrm{~s})$ to the north (Shaman; de Porras et al. 2012; Stern et al. 2015a) and south

(Augusta; Villa-Martínez et al. 2012; Stern et al. 2013, 2015b) from which tephra from SSVZ volcanoes have previously been reported. The $10-\mathrm{cm}$ isopachs for some of the previously documented medium to large Holocene and Late Glacial eruptions of SSVZ volcanoes (MEL1; MEN1; MAC1 and Hudson Ho, H1, H2, and H3 phase 2) are taken from Scasso et al. (1994), Naranjo and Stern (1998, 2004), Weller et al. (2014), and Stern et al. (2015b) 
This paper presents a high-resolution tephrochronology of explosive eruptions of southernmost Andean Southern Volcanic Zone (SSVZ) volcanoes since the beginning of the last glacial termination based on the tephra record preserved in lacustrine sediment cores collected from eight small lakes to the southeast of the SSVZ volcanoes near the town of Coyhaique (Fig. 1; Fig. S1 in the supplementary files). This portion of the Andes was heavily glaciated during the last glaciation. Retreat of the glaciers, beginning at approximately 17,800 calibrated years before present (cal years BP) as indicated by the ages of the deepest organic sediment layers in each core (Table S1 in the supplementary files; Miranda et al. 2013), generated many small shallow lakes with limited catchment areas in the semiarid region to the southeast of the volcanic arc. These lakes provide favorable environments for the preservation of the tephra produced by explosive eruptions of the SSVZ volcanoes extending back into the Late Glacial period.

Tephra from a very large Late Glacial age explosive eruption (Ho) of Hudson volcano was previously recognized in these same cores (Weller et al. 2014). This study identifies and characterizes lithostratigraphic and petrochemical information for the tephra from many more ( $>60$; Fig. 2, Tables 1 and 2) previously undocumented smaller explosive eruptions of Hudson, Mentolat, Macá, and possibly, either Cay or one of the many minor MECs in the region. These results constrain a better understanding of both the eruption frequency of these volcanoes through time and the variability in their volcanic products. They provide isochrones (tephra horizons of equal age; Lowe 2011; Fontijn et al. 2014) which can be utilized, at least in the cases of the larger eruptions, to constrain the age of tephra in palaeoclimatic, palaeoecologic, and archaeologic records in the region as well as to allow for synchronization of terrestrial tephra airfall outcrop studies with lacustrine and oceanic records. They are also significant for evaluating the volcanic risk for local population centers, such as Coyhaique, one of the fastest-growing cities in Chile.

\section{Geologic background}

The Andean SVZ results from the subduction of the Nazca Plate beneath the Southern American Plate (Fig. 1; Stern 2004). Hudson, the southernmost volcanic center in the SVZ, sits $\sim 280 \mathrm{~km}$ to the east of the Chile Rise-Trench triple junction, an active spreading center that separates the Antarctic and Nazca plates. Over the last 15-20 Ma, the triple junction has migrated northward along the continental margin as a result of the oblique collision between the ridge and the trench (Cande and Leslie 1986; Nelson et al. 1994). Just to the south of Hudson, there is a gap in volcanic activity that separates the SVZ from the Austral Volcanic Zone (AVZ; Stern and Kilian 1996; Stern 2004). The major volcanic centers of the SSVZ

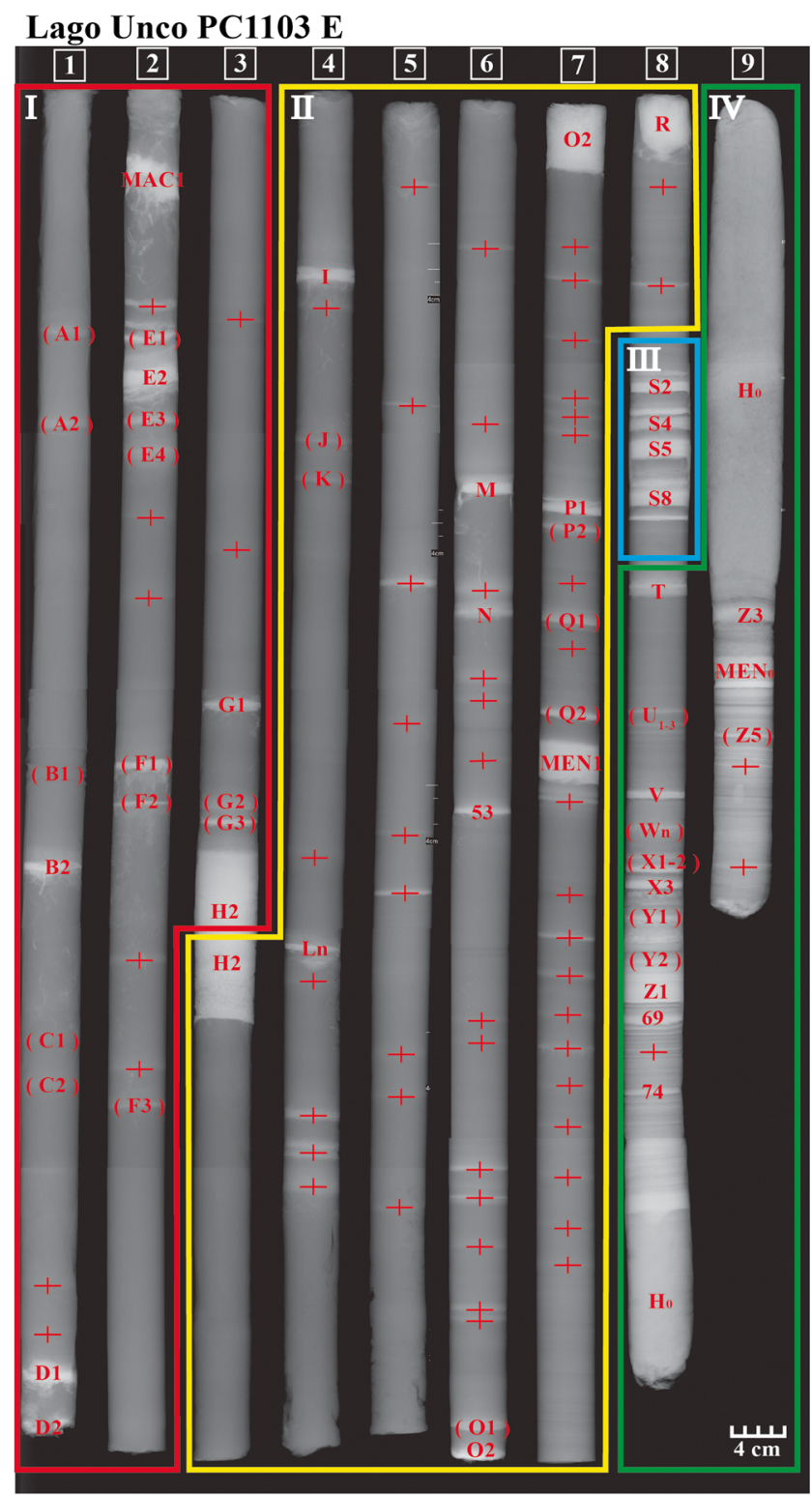

Fig. 2 X-ray image of the $8.5 \times 1 \mathrm{~m}$ sections of the core from Lago Unco. The $>70$ different tephras in this core appear as white layers due to their higher density compared to the predominantly organic lake sediments in which they are preserved. Sampled and unsampled (in parentheses) tephras from 59 eruptions that have been correlated with tephras in other cores are labeled $A 1$ through $Z 3$ (Table 1). The samples of three tephras not correlated with tephras in other cores are labeled by their depth in centimeters in each section (T1-9) of the core (T6-53, T8-69, and $T 8-74$ ), and numerous thin unsampled dense layers, most probably tephra, are indicated by $a+$ symbol. The core has been divided into four zones (zone I from the top to tephra $\mathrm{H} 2$, zone II from tephra $\mathrm{H} 2$ to the top of the sequence of tephras S1-10, zone III the sequence S1-10, zone IV from $\mathrm{S} 10$ to the bottom of the core) for the purpose of describing the different tephras

occur just to the east and west of the arc-parallel LOFS (Cembrano et al. 1996; D’Orazio et al. 2003; Vargas et al. 2013). This fault system originated in response to the impingement of the Chile Rise against the continent and the 
Table 1 Thickness $(\mathrm{cm})$ of 61 tephras correlated in cores from multiple lakes

\begin{tabular}{|c|c|c|c|c|c|c|c|c|c|c|c|c|}
\hline & \multirow[t]{2}{*}{ Tephra } & \multirow[t]{2}{*}{ Chemical type } & \multirow[t]{2}{*}{ Source } & \multicolumn{4}{|c|}{ Southern lakes } & \multicolumn{4}{|c|}{ Northern lakes } & \multirow[t]{2}{*}{$\operatorname{Ages}^{\mathrm{a}}(\mathrm{cal}$ years BP) } \\
\hline & & & & Espejo & Quijada & Churrasco & Élida & Unco & Mellizas & El Toro & Tranquilo & \\
\hline \multirow[t]{20}{*}{ Zone I } & A1 & LAM & $\mathrm{M} / \mathrm{C} / \mathrm{MEC}$ & $\operatorname{Tr}$ & $\operatorname{Tr}$ & - & - & $\operatorname{Tr}$ & $\operatorname{Tr}$ & 1 & $\operatorname{Tr}$ & \\
\hline & $\mathrm{A} 2$ & - & - & $\operatorname{Tr}$ & $\operatorname{Tr}$ & - & - & $\operatorname{Tr}$ & $\operatorname{Tr}$ & $\operatorname{Tr}$ & $\operatorname{Tr}$ & \\
\hline & B1 & - & - & $\operatorname{Tr}$ & $\operatorname{Tr}$ & $\operatorname{Tr}$ & - & $\operatorname{Tr}$ & $\operatorname{Tr}$ & - & - & \\
\hline & $\mathrm{B} 2$ & LAF & MEN & $\operatorname{Tr}$ & $\operatorname{Tr}$ & $\operatorname{Tr}$ & - & 1 & $\operatorname{Tr}$ & 1 & 4 & \\
\hline & $\mathrm{C} 1$ & HA & HUD & 3 & 1 & 1 & - & $\operatorname{Tr}$ & 3 & $<1$ & $<1$ & \\
\hline & $\mathrm{C} 2$ & HA & HUD & $<1$ & $<1$ & 1 & - & $\operatorname{Tr}$ & - & 1 & 1 & \\
\hline & D1 & LAF & MEN & - & - & $<1$ & - & 1 & $<1$ & $<1$ & - & \\
\hline & $\mathrm{D} 2$ & HA & HUD & - & - & 1 & - & 1 & $<1$ & 1 & 1 & \\
\hline & $\mathrm{D} 3=\mathrm{MAC} 1$ & LAM & MACA & 2 & 2 & 1 & - & 1 & 8 & 7 & 8 & $1440 \pm 60$ \\
\hline & E1 & HA & HUD & 1 & - & - & - & $<1$ & - & $<1$ & 1 & \\
\hline & E2 & HA & HUD & 3 & 1 & 2 & - & 1 & 3 & 3 & 2 & \\
\hline & E3 & LAM & $\mathrm{M} / \mathrm{C} / \mathrm{MEC}$ & 2 & - & - & - & 1 & - & $<1$ & 1 & \\
\hline & $\mathrm{E} 4$ & - & - & $<1$ & $<1$ & $\operatorname{Tr}$ & - & $\operatorname{Tr}$ & - & 1 & $<1$ & \\
\hline & $\mathrm{F} 1$ & HA & HUD & $<1$ & 1 & 1 & 1 & 1 & 1 & 1 & 1 & \\
\hline & $\mathrm{F} 2$ & HA & HUD & 1 & $<1$ & 1 & $>1$ & $<1$ & $\operatorname{Tr}$ & $\operatorname{Tr}$ & - & \\
\hline & $\mathrm{F} 3=\mathrm{T} 6$ & HA & HUD & 1 & $<1$ & 1 & - & $<1$ & $\operatorname{Tr}$ & $\operatorname{Tr}$ & - & $2235 \pm 120$ \\
\hline & G1 & LAM & $\mathrm{M} / \mathrm{C} / \mathrm{MEC}$ & 1 & $<1$ & 1 & 1 & 1 & 2 & 1 & 1 & \\
\hline & G2 & LAM & $\mathrm{M} / \mathrm{C} / \mathrm{MEC}$ & 2 & 1 & $<1$ & $\operatorname{Tr}$ & $\operatorname{Tr}$ & $\operatorname{Tr}$ & $<1$ & $<1$ & \\
\hline & G3 & LAM & $\mathrm{M} / \mathrm{C} / \mathrm{MEC}$ & 1 & - & 1 & 1 & 1 & $<1$ & $<1$ & $\operatorname{Tr}$ & \\
\hline & $\mathrm{H} 2$ & HA & HUD & 53 & 24 & 24 & 14 & 12 & 14 & 8 & 11 & $4000 \pm 50$ \\
\hline \multirow[t]{15}{*}{ Zone II } & I & HA & HUD & 2 & $\operatorname{Tr}$ & $\operatorname{Tr}$ & 2 & 1 & - & - & - & \\
\hline & $\mathrm{J}$ & HA & HUD & 1 & 1 & 1 & 1 & $\operatorname{Tr}$ & - & - & - & \\
\hline & $\mathrm{K}$ & HA & HUD & 1 & $<1$ & 1 & 1 & $\operatorname{Tr}$ & - & - & - & \\
\hline & Ls & LAM & $\mathrm{M} / \mathrm{C} / \mathrm{MEC}$ & - & - & 1 & 1 & - & - & - & - & \\
\hline & $\mathrm{Ln}$ & LAF & MEN & - & - & - & - & 1 & - & 1 & 1 & \\
\hline & M & HA & HUD & 2 & 1 & 2 & 1 & $\operatorname{Tr}$ & - & - & - & \\
\hline & $\mathrm{N}$ & HA & HUD & 5 & 5 & 3 & 4 & 1 & - & - & - & \\
\hline & $\mathrm{O} 1$ & LAF & MEN & $\operatorname{Tr}$ & - & $\operatorname{Tr}$ & $<1$ & $<1$ & 1 & $<1$ & - & \\
\hline & $\mathrm{O} 2$ & LAM & $\mathrm{M} / \mathrm{C} / \mathrm{MEC}$ & - & - & 1 & $\operatorname{Tr}$ & 6 & 5 & 5 & - & \\
\hline & $\mathrm{P} 1$ & LAM & $\mathrm{M} / \mathrm{C} / \mathrm{MEC}$ & $\operatorname{Tr}$ & 1 & 1 & 1 & 1 & 5 & $<1$ & - & \\
\hline & $\mathrm{P} 2$ & HA & HUD & 1 & 1 & 1 & 1 & $<1$ & - & $<1$ & - & \\
\hline & Q1 & LAF & MEN & $<1$ & $\operatorname{Tr}$ & 2 & $<1$ & $<1$ & 1 & $<1$ & 9 & \\
\hline & Q2 & LAF & MEN & - & - & - & - & 1 & - & 3 & 6 & \\
\hline & MEN1 & LAF & MEN & $<1$ & 1 & 1 & 1 & 3 & 2 & 3 & 4 & $7670 \pm 60$ \\
\hline & $\mathrm{R}$ & LAF & MEN & $<1$ & $<1$ & $<1$ & $<1$ & 3 & 4 & - & 1 & \\
\hline \multirow[t]{10}{*}{ Zone III } & $\mathrm{S} 1$ & HA & HUD & 1 & 1 & $<1$ & - & $<1$ & - & 2 & 1 & $14,088 \pm 40$ \\
\hline & $\mathrm{S} 2$ & HA & HUD & 1 & 1 & 1 & 1 & 1 & 1 & 1 & 1 & \\
\hline & S3 & HA & HUD & 1 & 1 & 1 & 1 & $<1$ & $<1$ & $<1$ & 1 & \\
\hline & S4 & HA & HUD & 2 & 1 & 3 & 1 & 1 & 1 & 1 & $<1$ & \\
\hline & S5 & HA & HUD & 3 & 2 & 1 & 1 & 2 & 2 & 1 & 1 & \\
\hline & S6 & HA & HUD & 1 & $<1$ & $<1$ & $<1$ & $\operatorname{Tr}$ & $\operatorname{Tr}$ & $<1$ & $\operatorname{Tr}$ & \\
\hline & S7 & HA & HUD & 1 & $<1$ & 1 & 1 & $<1$ & $<1$ & $<1$ & $<1$ & \\
\hline & S8 & HA & HUD & 2 & 2 & 2 & 1 & 1 & $<1$ & $<1$ & $<1$ & \\
\hline & S9 & HA & HUD & 1 & $>1$ & - & 1 & $<1$ & $<1$ & $<1$ & - & \\
\hline & S10 & HA & HUD & $<1$ & 1 & - & 1 & $\operatorname{Tr}$ & - & $<1$ & $\operatorname{Tr}$ & $14,931 \pm 30$ \\
\hline \multirow[t]{2}{*}{ Zone IV } & $\mathrm{T}$ & LAF & MEN & - & - & - & - & 1 & 1 & 1 & 1 & \\
\hline & U1 & - & - & $<1$ & $<1$ & $\operatorname{Tr}$ & 1 & $<1$ & $<1$ & $<1$ & $<1$ & \\
\hline
\end{tabular}


Table 1 (continued)

\begin{tabular}{|c|c|c|c|c|c|c|c|c|c|c|c|}
\hline \multirow[t]{2}{*}{ Tephra } & \multirow[t]{2}{*}{ Chemical type } & \multirow[t]{2}{*}{ Source } & \multicolumn{4}{|c|}{ Southern lakes } & \multicolumn{4}{|c|}{ Northern lakes } & \multirow[t]{2}{*}{$\operatorname{Ages}^{\mathrm{a}}$ (cal years BP) } \\
\hline & & & Espejo & Quijada & Churrasco & Élida & Unco & Mellizas & El Toro & Tranquilo & \\
\hline $\mathrm{U} 2$ & - & - & 1 & $<1$ & $\operatorname{Tr}$ & 1 & $\operatorname{Tr}$ & $<1$ & - & - & \\
\hline U3 & - & - & $<1$ & $<1$ & - & - & $\operatorname{Tr}$ & $\operatorname{Tr}$ & - & - & \\
\hline V & HA & HUD & 1 & 1 & 1 & $<1$ & 1 & 1 & 1 & 1 & \\
\hline Ws & HA & HUD & 2 & $<1$ & $<1$ & $<1$ & - & - & - & - & \\
\hline Wn & LAM & M/C/MEC & & - & - & - & $\operatorname{Tr}$ & $<1$ & 1 & - & \\
\hline $\mathrm{X} 1$ & HA & HUD & & $<1$ & $<1$ & - & $\operatorname{Tr}$ & $<1$ & $<1$ & $\operatorname{Tr}$ & \\
\hline $\mathrm{X} 2$ & HA & HUD & & 1 & 1 & 1 & $<1$ & $<1$ & 1 & 1 & \\
\hline $\mathrm{X} 3$ & HA & HUD & & 1 & 1 & 1 & 1 & 1 & $<1$ & $<1$ & \\
\hline Y1 & LAM & $\mathrm{M} / \mathrm{C} / \mathrm{MEC}$ & & 1 & 1 & 1 & $<1$ & $<1$ & 1 & $<1$ & \\
\hline $\mathrm{Y} 2$ & - & - & & $<1$ & - & - & - & $<1$ & $<1$ & - & \\
\hline $\mathrm{Z1}$ & HA & HUD & & 9 & 2 & - & 3 & 4 & 3 & 4 & \\
\hline $\mathrm{Z2}=\mathrm{Ho}$ & HA & HUD & & 88 & 64 & 19 & 58 & 68 & 32 & 61 & $17,370 \pm 70$ \\
\hline $\mathrm{Z3}$ & LAM & $\mathrm{M} / \mathrm{C} / \mathrm{MEC}$ & & 1 & 1 & - & 1 & 2 & 1 & 10 & \\
\hline $\mathrm{Z} 4=\mathrm{MENo}$ & LAF & MEN & & - & - & - & 3 & 3 & 1 & - & \\
\hline $\mathrm{Z} 5$ & LAM & $\mathrm{M} / \mathrm{C} / \mathrm{MEC}$ & & - & - & - & - & 1 & 1 & - & $<17,445 \pm 45$ \\
\hline
\end{tabular}

${ }^{a}$ Ages of MAC1 from Naranjo and Stern (2004), H2 from Naranjo and Stern (1998), MEN1 from Stern et al. (2015b), Ho from Weller et al. (2014), and S1 and S10 from Miranda et al. (2013)

$\operatorname{Tr}$ trace $(<0.5 \mathrm{~cm})$; HUD Hudson; MEN Mentolat; M/C/MEC Macá, Cay, and/or minor eruptive centers; HA high abundance; LAM low-abundance mafic; $L A F$ low-abundance felsic

oblique subduction of the Nazca Plate underneath South America (Nelson et al. 1994; Cembrano et al. 1996).

According to Völker et al. (2011), the average volcanic extrusion rates in the Andean arc decrease southwards from $9.9 \mathrm{~km}^{3} / \mathrm{km}$ in the Central SVZ north of $41^{\circ} \mathrm{S}$ to only $2.2 \mathrm{~km}^{3} /$ $\mathrm{km}$ in the southernmost part of the SVZ south of where the Guafo Fracture Zone enters the Chile Trench at $\sim 44^{\circ}$ S. Despite this southward regional reduction in the estimated average extrusion rate, Hudson volcano is larger $\left(147 \mathrm{~km}^{3}\right)$ than average SVZ volcanic edifices $\left(\sim 100 \mathrm{~km}^{3}\right)$. Hudson, with a documented history of over 1 million years (Orihashi et al. 2004), is also older than average SVZ centers. Nevertheless, Hudson volcano, which is the only volcano in the SSVZ to have had historic activity (Gonzáles-Ferrán 1994), has erupted a large volume of pyroclastic material since the beginning of glacial retreat ( $>45 \mathrm{~km}^{3}$; Weller et al. 2014) and, as a result, has a high proportion $(\sim 30 \%)$ of pyroclastic material not included in the estimate of its total volume made by Völker et al. (2011). Therefore, the Holocene activity of Hudson has clearly been anomalous compared to other volcanoes in the SVZ. In contrast, Völker et al. (2011) estimated the volumes of the Mentolat, Cay, and Macá volcanoes, which, like Hudson, might be much older than Holocene, as only between 40 and $50 \mathrm{~km}^{3}$ each, and the numerous Holocene minor monogenetic eruptive centers (MECs) in this zone have an even smaller volume $\left(<<10 \mathrm{~km}^{3}\right.$ total $)$.

Melimoyu volcano (Fig. 1), which is formed by basalts, andesites, and dacites (López-Escobar et al. 1993; Naranjo and Stern 2004), has had two large and a number of smaller Holocene explosive eruptions (Naranjo and Stern 2004; Stern et al. 2015a), but there is no evidence of Melimoyu tephras dispersed as far to the south as Coyhaique. Mentolat is formed by basaltic andesite and andesite lavas (López-Escobar et al. 1993) capped by a summit crater filled with an ice-covered dome (see Fig. 13 in Naranjo and Stern 2004). A light gray andesitic tephra deposit (MEN1; Fig. 1), dated at approximately $7690 \pm 60 \mathrm{cal}$ years BP (Stern et al. 2015b), has been observed in outcrops northwest of Coyhaique (Naranjo and Stern 2004) and also in cores from both Lago Shaman (Fig. 1) east of the volcano (de Porras et al. 2012; Stern et al. 2015a) and from other small lakes, such as Augusta (Fig. 1), and trenches in bogs south of Coyhaique near the town of Cochrane (Fig. 1; Villa-Martínez et al. 2012; Stern et al. 2013, 2015b). Two other younger tephras which crop out in the vicinity of Mentolat volcano have been attributed to eruptions of this volcano at $<2560$ and 4320 cal years BP, respectively (Mella et al. 2012), and tephra from these events as well as six tephras derived from other eruptions of Mentolat have been observed in cores from Lago Shaman (Fig. 1) and Mallín el Embudo east of the volcano (de Porras et al. 2012, 2014; Stern et al. 2015a).

Forty-five kilometers south of Mentolat, Cay is a highly eroded stratovolcano formed by basalts, basaltic andesites, and dacites (Futa and Stern 1988; López-Escobar et al. 1993; D'Orazio et al. 2003). There are no previous observations of Holocene tephra deposits attributed to 
Table 2 Maximum grain size $(\mathrm{mm})$ of tephras in cores from multiple lakes

\begin{tabular}{|c|c|c|c|c|c|c|c|c|c|c|}
\hline & \multirow[t]{2}{*}{ Tephra } & \multirow[t]{2}{*}{ Source } & \multicolumn{4}{|c|}{ Southern lakes } & \multicolumn{4}{|c|}{ Northern lakes } \\
\hline & & & Espejo & Quijada & Churrasco & Élida & Unco & Mellizas & El Toro & Tranquilo \\
\hline \multirow[t]{17}{*}{ Zone I } & A1 & $\mathrm{M} / \mathrm{C} / \mathrm{MEC}$ & - & - & - & - & - & - & 0.6 & - \\
\hline & B2 & MEN & - & - & - & - & 0.6 & - & 0.6 & 1.0 \\
\hline & $\mathrm{C} 1$ & HUD & 0.8 & 0.8 & 0.6 & - & - & 0.2 & - & - \\
\hline & $\mathrm{C} 2$ & HUD & - & - & 0.3 & - & - & - & 0.2 & 0.2 \\
\hline & D1 & MEN & - & - & - & - & 1.2 & - & - & - \\
\hline & D2 & HUD & - & - & 0.6 & - & 0.6 & - & - & 0.4 \\
\hline & $\mathrm{D} 3=\mathrm{MAC} 1$ & MACA & 1.0 & 1.0 & 1.2 & - & 1.2 & 1.2 & 1.4 & 1.0 \\
\hline & E1 & HUD & 0.4 & - & - & - & - & - & - & 0.4 \\
\hline & E2 & HUD & 0.8 & 0.8 & 0.6 & - & 0.6 & 0.5 & 0.6 & 0.4 \\
\hline & E3 & $\mathrm{M} / \mathrm{C} / \mathrm{MEC}$ & 0.5 & - & - & - & 0.5 & - & - & 0.5 \\
\hline & $\mathrm{F} 1$ & HUD & 0.8 & 0.6 & 0.3 & 1.0 & - & 0.3 & 0.3 & 0.1 \\
\hline & $\mathrm{F} 2$ & HUD & 0.5 & - & - & - & - & - & - & - \\
\hline & $\mathrm{F} 3=\mathrm{T} 6$ & HUD & 0.5 & - & 0.4 & - & - & - & - & - \\
\hline & G1 & $\mathrm{M} / \mathrm{C} / \mathrm{MEC}$ & 0.6 & - & 0.6 & 0.8 & 1.0 & 0.8 & 0.8 & 0.8 \\
\hline & $\mathrm{G} 2$ & $\mathrm{M} / \mathrm{C} / \mathrm{MEC}$ & 0.6 & 0.7 & - & - & - & - & - & - \\
\hline & G3 & $\mathrm{M} / \mathrm{C} / \mathrm{MEC}$ & 0.6 & - & 0.8 & 0.4 & - & - & - & - \\
\hline & $\mathrm{H} 2$ & HUD & 24 & 20 & 16 & - & 7.0 & 5.0 & 5.0 & 5.0 \\
\hline \multirow[t]{15}{*}{ Zone II } & I & HUD & 0.4 & - & - & 0.6 & 0.3 & - & - & - \\
\hline & $\mathrm{J}$ & HUD & 0.2 & 0.3 & 0.4 & 0.5 & - & - & - & - \\
\hline & $\mathrm{K}$ & HUD & 0.8 & - & 0.9 & 0.6 & - & - & - & - \\
\hline & $\mathrm{Ls}$ & $\mathrm{M} / \mathrm{C} / \mathrm{MEC}$ & - & - & 0.4 & 0.6 & - & - & - & - \\
\hline & $\mathrm{Ln}$ & MEN & - & - & - & - & 0.6 & - & 0.6 & 0.8 \\
\hline & M & HUD & 0.6 & 0.8 & 1.0 & 0.6 & 0.4 & - & - & - \\
\hline & $\mathrm{N}$ & HUD & 1.0 & 0.8 & 0.6 & 0.8 & 0.4 & - & - & - \\
\hline & $\mathrm{O} 1$ & MEN & - & - & - & - & - & 0.6 & - & - \\
\hline & $\mathrm{O} 2$ & $\mathrm{M} / \mathrm{C} / \mathrm{MEC}$ & - & - & 1.0 & - & 0.8 & - & 0.8 & - \\
\hline & $\mathrm{P} 1$ & $\mathrm{M} / \mathrm{C} / \mathrm{MEC}$ & - & 0.3 & 0.2 & 0.3 & 0.2 & 0.8 & - & - \\
\hline & $\mathrm{P} 2$ & HUD & 0.6 & 0.6 & 0.5 & 0.9 & - & - & - & - \\
\hline & Q1 & MEN & - & - & 0.4 & - & - & 0.6 & - & 2.5 \\
\hline & Q2 & MEN & - & - & - & - & - & - & 2.7 & 3 \\
\hline & MEN1 & MEN & - & 0.6 & 0.8 & 1.0 & 1.0 & 1.4 & 2.0 & 2.4 \\
\hline & $\mathrm{R}$ & MEN & - & - & - & - & 2.0 & 2.0 & - & 1.5 \\
\hline \multirow[t]{10}{*}{ Zone III } & $\mathrm{S} 1$ & HUD & 0.8 & 0.6 & - & - & - & - & 0.8 & 0.8 \\
\hline & $\mathrm{S} 2$ & HUD & 0.4 & 0.4 & 0.4 & 0.6 & 0.3 & 0.3 & 0.4 & 0.3 \\
\hline & $\mathrm{S} 3$ & HUD & 0.8 & 0.8 & & 0.6 & - & - & - & 0.6 \\
\hline & $\mathrm{S} 4$ & HUD & 0.6 & 0.5 & 0.6 & 0.4 & 1.2 & 1.2 & 1.4 & - \\
\hline & S5 & HUD & 0.6 & 0.6 & 0.5 & 0.4 & 0.5 & 0.5 & 0.6 & 0.3 \\
\hline & S6 & HUD & 0.6 & - & - & - & - & - & - & - \\
\hline & S7 & HUD & - & - & - & 0.5 & - & - & - & - \\
\hline & S8 & HUD & 0.4 & 0.4 & 0.5 & - & - & - & - & - \\
\hline & S9 & HUD & 0.6 & - & - & - & - & - & - & - \\
\hline & $\mathrm{S} 10$ & HUD & - & - & - & 0.8 & - & - & - & - \\
\hline \multirow[t]{5}{*}{ Zone IV } & $\mathrm{T}$ & MEN & - & - & - & - & 0.5 & 0.6 & 0.8 & 0.8 \\
\hline & V & HUD & 0.6 & 0.6 & 0.6 & - & 0.4 & 0.4 & 0.4 & 0.2 \\
\hline & Ws & HUD & 0.4 & - & - & - & - & - & - & - \\
\hline & Wn & $\mathrm{M} / \mathrm{C} / \mathrm{MEC}$ & - & - & - & - & - & 0.3 & 0.4 & - \\
\hline & $\mathrm{X} 1$ & HUD & - & - & 0.3 & - & - & - & - & - \\
\hline
\end{tabular}


Table 2 (continued)

\begin{tabular}{|c|c|c|c|c|c|c|c|c|c|}
\hline \multirow[t]{2}{*}{ Tephra } & \multirow[t]{2}{*}{ Source } & \multicolumn{4}{|c|}{ Southern lakes } & \multicolumn{4}{|c|}{ Northern lakes } \\
\hline & & Espejo & Quijada & Churrasco & Élida & Unco & Mellizas & El Toro & Tranquilo \\
\hline $\mathrm{X} 2$ & HUD & - & 0.3 & 0.3 & 0.4 & - & - & 0.4 & 0.3 \\
\hline $\mathrm{X} 3$ & HUD & - & 0.6 & - & 0.6 & 0.5 & 0.2 & - & 0.3 \\
\hline Y1 & $\mathrm{M} / \mathrm{C} / \mathrm{MEC}$ & - & - & 0.2 & 0.3 & - & - & 0.4 & - \\
\hline $\mathrm{Z1}$ & HUD & - & 0.8 & 0.6 & - & 0.6 & 0.6 & 0.6 & 0.4 \\
\hline $\mathrm{Z3}$ & $\mathrm{M} / \mathrm{C} / \mathrm{MEC}$ & - & - & 0.4 & - & 0.3 & 0.4 & 0.3 & 0.6 \\
\hline $\mathrm{Z} 4=\mathrm{MENo}$ & MEN & - & - & - & - & 0.6 & 0.8 & 0.8 & - \\
\hline $\mathrm{Z5}$ & $\mathrm{M} / \mathrm{C} / \mathrm{MEC}$ & - & - & - & - & - & 0.6 & 0.5 & - \\
\hline
\end{tabular}

this volcano. Macá, located at the northwest end of a prominent NW-SE trending volcanic ridge $15 \mathrm{~km}$ to the west of Cay, is a partially eroded stratovolcano composed of basalts and basaltic andesites (Futa and Stern 1988; López-Escobar et al. 1993; D’Orazio et al. 2003; Gutiérrez et al. 2005). Outcrops northwest of Coyhaique of basaltic andesite MAC1 tephra
Fig. 3 a Ti versus $\mathrm{Rb}$ and $\mathbf{b} \mathrm{Sr}$ versus $\mathrm{Ba}$ concentrations, in parts per million ( $p p m)$, for published data of lavas (small solid symbols) and tephras (small open symbols) from Hudson, Mentolat, Macá, Cay, and MEC (Futa and Stern 1988; López-Escobar et al. 1993, 1995; Naranjo and Stern 1998, 2004; D’Orazio et al. 2003; Gutiérrez et al. 2005; Stern et al. 2015a, b), and bulk tephras from this study (larger labeled open symbols; Tables 2, 3, 4, and 5). The Hudson samples are all highabundance (HA) types with generally higher $\mathrm{Ti}, \mathrm{Rb}$, and $\mathrm{Ba}$ than both the low-abundance mafic samples from Macá, Cay, and MEC and the low-abundance felsic samples, which contain amphibole and clear glass (Fig. 4), from Mentolat

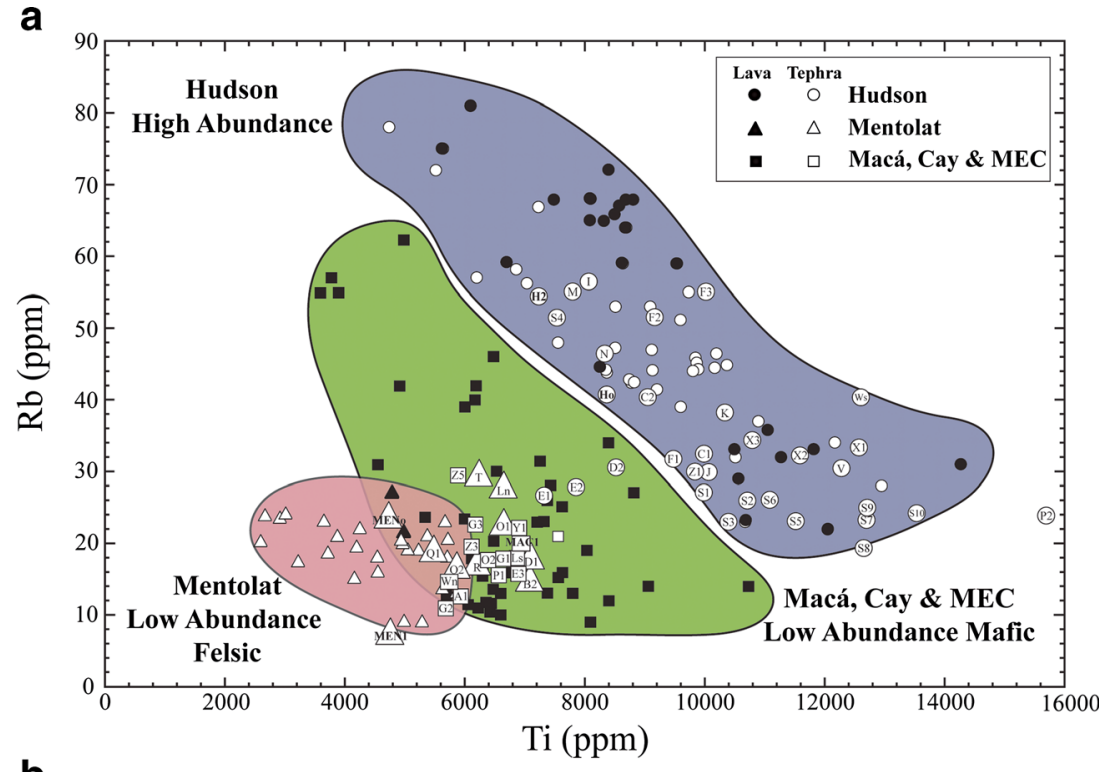

b

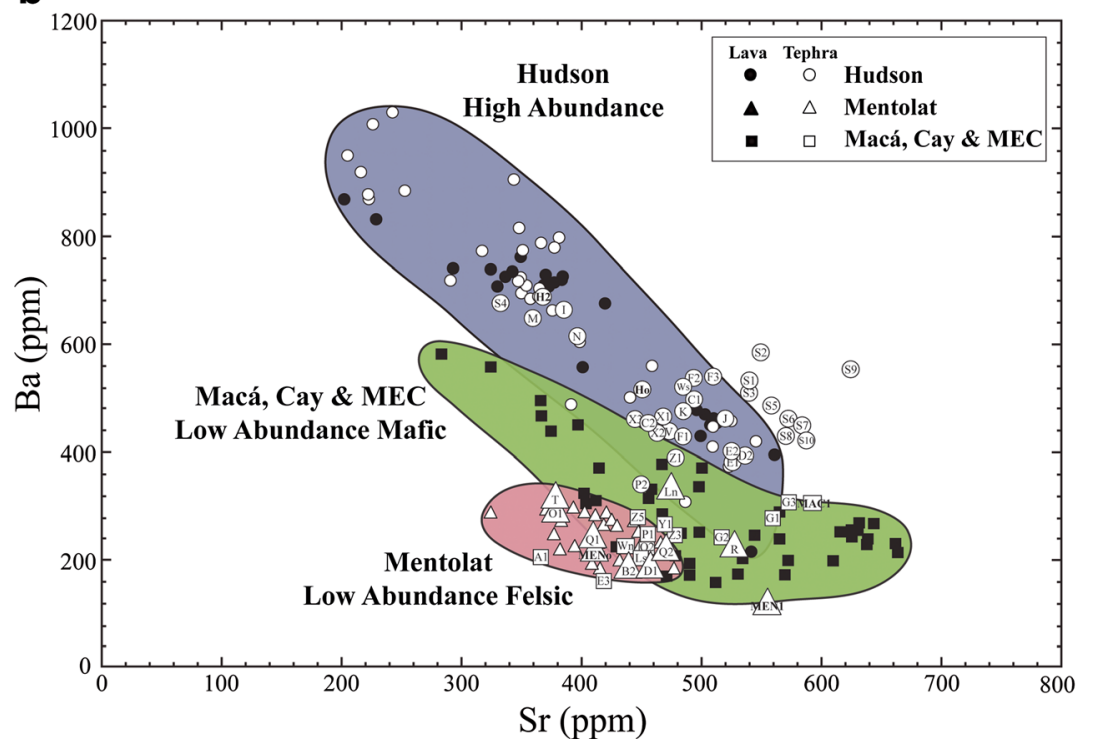


Fig. 4 Photomicrographs of petrochemically distinct types of tephra from different source volcanoes. a, b Hudson-derived $\mathrm{H} 2$ tephra containing light brown glass with elongate cylindrical vesicles and phenocrysts of plagioclase, clinopyroxene, and orthopyroxene. c, d Mentolatderived MEN1 phenocryst-rich tephra containing plagioclase, clinopyroxene and orthopyroxene, brown amphibole, and colorless glass with abundant undeformed vesicles and no mineral microlites. e, f MAC1 tephra, derived from Macá, containing black glass with abundant mineral microlites and no visible vesicles
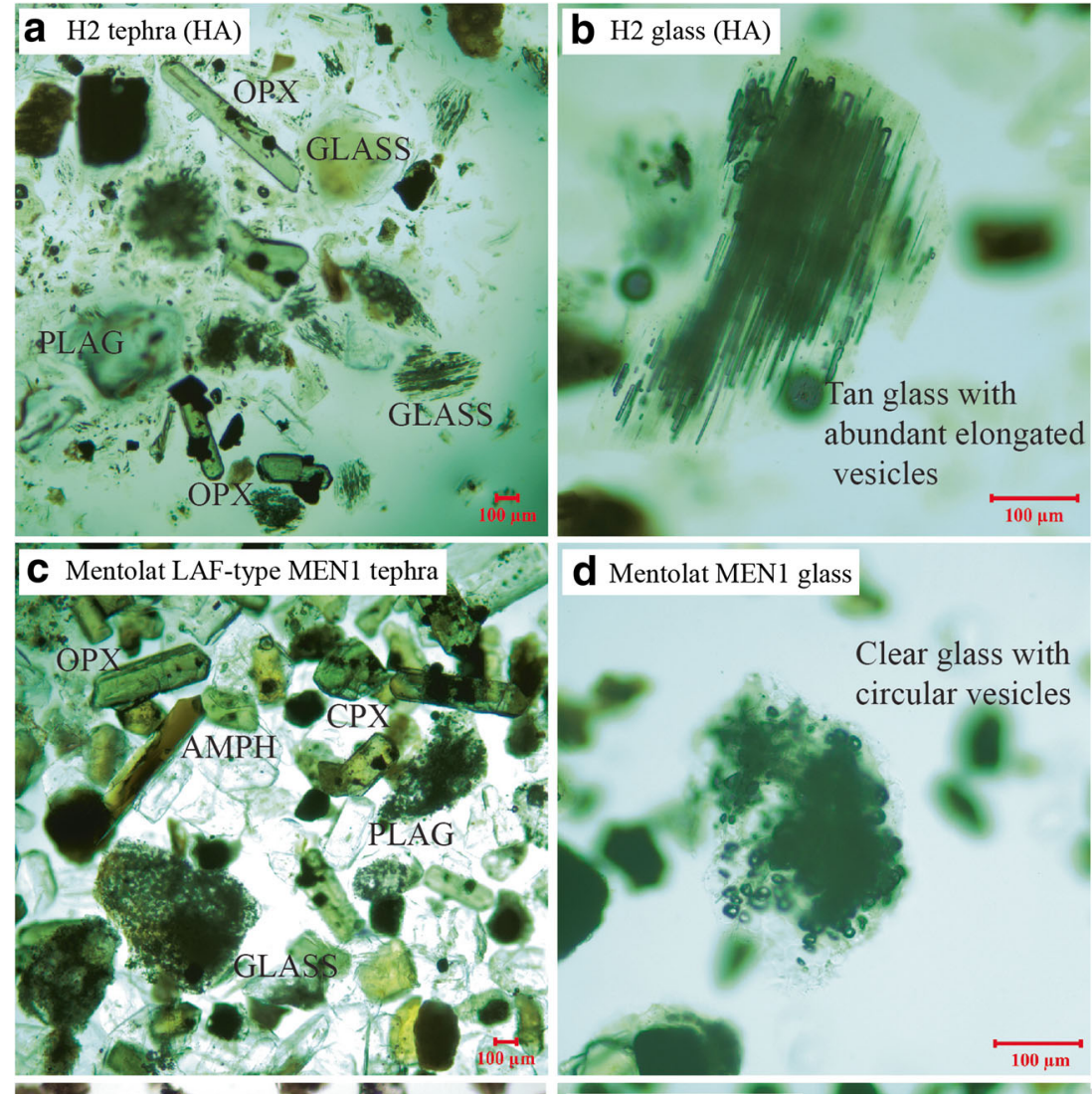

\section{d Mentolat MEN1 glass}
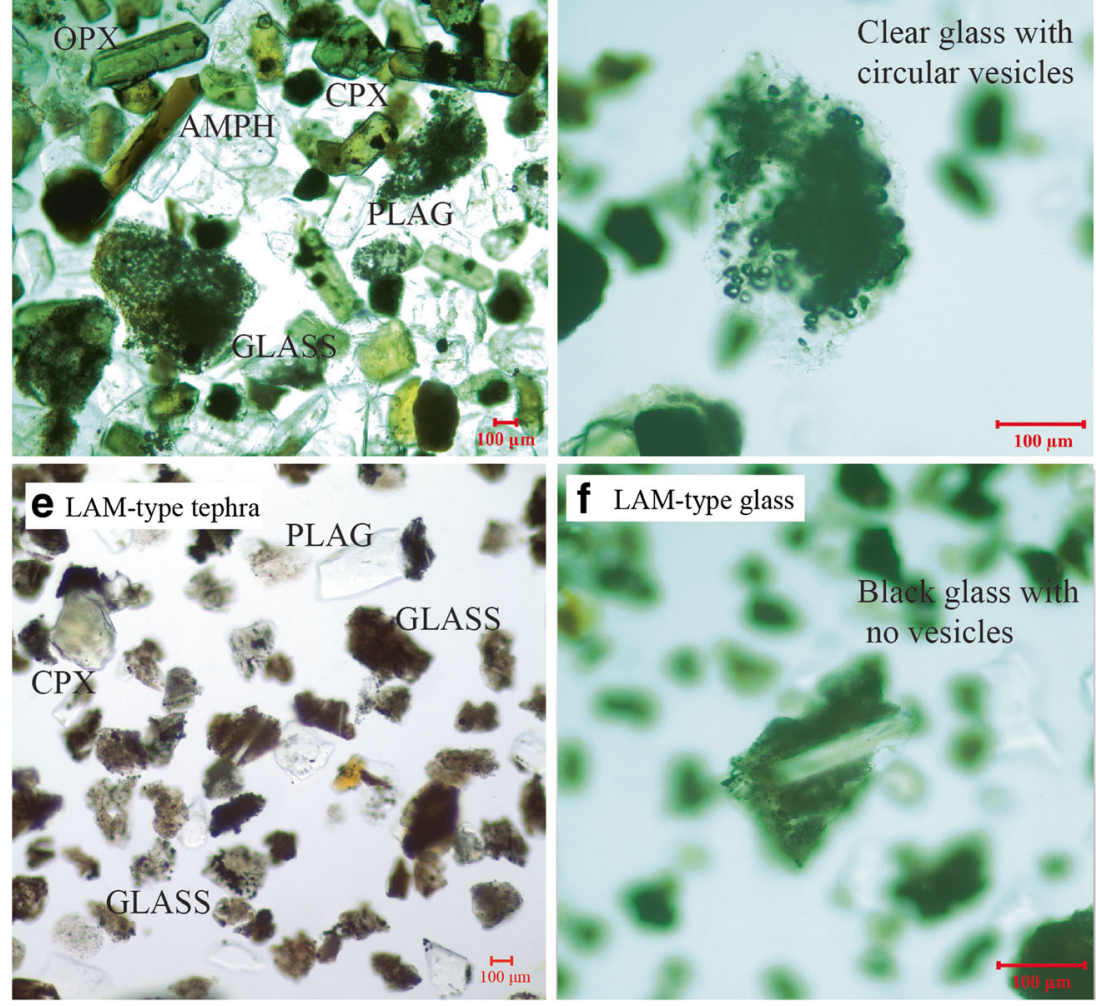

(Fig. 1), dated at $1440 \pm 40$ cal years BP, have been attributed to a medium-sized explosive eruption of this volcano (Naranjo and Stern 2004). Surrounding Macá and Cay volcanoes are numerous monogenetic cones that have erupted mostly basalts, but in some cases, basaltic andesites and andesites (D’Orazio et al. 2003; Gutiérrez et al. 2005; Vargas et al. 2013).

Hudson, the southernmost volcano of the SVZ, contains a 10-km-diameter ice-filled caldera (Naranjo and Stern 1998; Gutiérrez et al. 2005). Several historic eruptions from Hudson have been observed, including a small Plinian eruption in $1971 \mathrm{AD}$ that melted a part of the caldera ice fill and generated a large lahar (Best 1992), and the larger explosive H3 event in 1991 AD (>4 km³; Naranjo 1991; Scasso et al. 1994;
Kratzmann et al. 2009, 2010; Wilson et al. 2011, 2012). Additionally, evidence for multiple large explosive Late Glacial and Holocene eruptions from Hudson is preserved as tephra deposits observed in both outcrops and lacustrine sediment cores over a large region of southernmost Patagonia (Fig. 1), as far west as the Pacific Coast (Haberle and Lumley 1998), east to the Atlantic Coast, and as far south as Tierra del Fuego (Stern 1991, 2008; Naranjo and Stern 1998) and Isla de los Estados (Unkel et al. 2010; Björck et al. 2012), as well as in Pacific Ocean sediment cores (Siani et al. 2010, 2013; Carel et al. 2011). These eruptions include the $\sim 17,370 \pm$ 70 cal years BP Ho event $\left(>20 \mathrm{~km}^{3}\right.$; Weller et al. 2014), the $8170 \pm 60$ cal years BP H1 eruption $\left(>18 \mathrm{~km}^{3}\right.$; Stern 1991, 2008; Naranjo and Stern 1998; Stern et al. 2015b), and the 
$4000 \pm 50$ cal years BP H2 eruption $\left(>5 \mathrm{~km}^{3}\right.$; Naranjo and Stern 1998). Tephras from several other smaller Holocene eruptions of Hudson within excavated trenches, including a distinctive mafic tephra T6 dated as $2235 \pm 120$ cal years BP, have also been observed southeast of this volcano (Naranjo and Stern 1998).

Lavas and tephras from the SSVZ volcanoes fall in two distinguishable chemical groups which have been termed low-abundance (LA)- and high-abundance (HA)-type samples (Fig. 3; López-Escobar et al. 1993, 1995). Samples of lavas and tephras derived from Mentolat, Macá, Cay, and MEC volcanoes south of Mentolat are all LA types, while Hudson has erupted only HA lavas and tephra with distinctly higher incompatible large-ion lithophile (LIL; Cs, $\mathrm{Rb}, \mathrm{Ba}, \mathrm{Sr}$, $\mathrm{K}$, Th), rare earth element (REE), and high-field-strength element (HFSE; Ti, Zr, Nb, Hf, U) contents. For Hudson volcano, Carel et al. (2011) have demonstrated that Hudson's HA chemical characteristics are reflected in both bulk lava, tephra, and tephra glass chemical analysis.

Among the volcanoes characterized by the eruption of LA magmas, Mentolat andesites have, at any given $\mathrm{SiO}_{2}$, lower $\mathrm{K}_{2} \mathrm{O}$ (López-Escobar et al. 1993; Naranjo and Stern 2004; Stern et al. 2015b) and other LIL element (Fig. 3) concentrations than Macá, Cay, and MEC basalts and basaltic andesites. In this respect, they are similar to andesites erupted from other volcanoes further north along the SVZ volcanic front such as Huequi (Watt et al. 2011), Calbuco (López-Escobar et al. 1995), and Nevado de Longaví (Sellés et al. 2004), which, like Mentolat, all have an amphibole as a phenocryst phase (Fig. 4).

These chemical differences, along with petrographic characteristic and spatial distribution, have been used in the past to identify the SSVZ source volcanoes of specific tephra (Stern 1991, 2008; Naranjo and Stern 2004; Carel et al. 2011; Stern et al. 2013, 2015a, b; Weller et al. 2014). They are also used in this paper as a guide to the possible source volcanoes of tephra found in the sediment cores from the lakes near Coyhaique (Fig. 3).

\section{Methods}

Eight lakes were cored as part of a project to understand the palaeoclimatic evolution of this region of southern Patagonia (Miranda et al. 2013). These lakes, all formed by glacial scouring of the bedrock, were selected for sampling because of their small size ( $<800 \mathrm{~m}$ maximum diameter; $<1 \mathrm{~km}^{2}$ surface area), shallow depth $(<10 \mathrm{~m})$, and the limited area of their drainage catchments $\left(<10 \mathrm{~km}^{2}\right)$, which minimizes the volume of clastic sedimentary input from streams. They are all significantly smaller than other lakes in the region, such as Castor and Escondido (Fig. S1 in the supplementary files; Elbert et al. 2013), from which cores with tephra have been reported previously. Multiple sediment cores from each lake, which are stored in a refrigerator at the Universidad de Chile in Santiago, were obtained over a 3 -year period using a $5-\mathrm{cm}$ modified Livingston piston corer. The cores were collected at 1-m-length intervals until sediments transitioned from predominately organic matter-rich lacustrine to sand- and clayrich glacial sediments. The length of the sediment record for each lake is unique and is controlled by the duration since the glacial retreat and the sediment accumulation rate since that time. A preliminary chronology of some of the different tephras identified in the cores, specifically Ho (Weller et al. 2014) and the S1 to S10 sequence of tephra (Fig. 2), as well as the age of the earliest organic matter-rich sediment near the base of the cores, has been controlled by AMS radiocarbon dates of organic material in the sediments above and below these tephras (Table S1 in the supplementary files; Miranda et al. 2013; Weller et al. 2014). Radiocarbon dates were converted to calendar years before present (cal years BP) using the CALIB 7 program and the SHCal13 data set (Stuiver et al. 1998). The age of other tephras (D3 = MAC1 from Macá, $\mathrm{F} 3=\mathrm{T} 6$ and $\mathrm{H} 2$ from Hudson volcano, and MEN1 from Mentolat; Table 1) is controlled by previously determined ages from outcrops (Naranjo and Stern 1998, 2004) and other cores in the region (Elbert et al. 2013; Stern et al. 2015b). The ages of all the other previously unknown tephras in these cores have not been determined directly but can be roughly estimated based on their depth in the cores relative to these five dated tephras.

Each core segment was imaged using transmitted X-rays to aid in the identification of the tephra deposits. Figure 2 shows the X-ray images of the approximately $8.5 \mathrm{~m}$ of sediment cored from Lago Unco (core no. PC1103E). The darker layers are the less dense organic material-rich post-glacial lacustrine sediments, while the white layers within the cores are denser lithologies, generally tephra deposits, but also including sands in the deeper parts of the cores deposited during Late Glacial and/or glacial times. The X-ray image of the other seven lakes is contained in the supplementary files (Figs. S2-S8 in the supplementary files).

Thicker, visually identifiable tephra layers were removed from the lake cores with a knife. Over 400 tephra samples were collected from the cores over a 3-year period, but many of the very thin dense layers observed in the X-ray images of the cores were not sampled. Tephras were washed in water and acetone to remove organic matter. A portion of each tephra sample was mounted on a slide and examined under a petrographic microscope to characterize its grain size (Table 2) and petrography (Fig. 4, Table S2 in the supplementary files). A total of 290 bulk-tephra samples were powdered in a tungsten-moly shatter box and dissolved at $95^{\circ} \mathrm{C}$ in a mixture of $\mathrm{HF}, \mathrm{HCl}$, and $\mathrm{HNO}_{3}$ acids for trace element analysis using an ELAN DCR ICP-MS. Repeated analysis of internal lab standards, including a basalt, andesite, and rhyolite, 
was performed to determine precision, which is generally better than $10 \%$ at the concentration levels of the tephra, and an analysis of basalt samples BHVO1 and NIST2711 was performed to monitor accuracy (Table S11 of the supplementary files; Saadat and Stern 2011). The results of analyses of individual tephra from the different cores are presented in Tables S3-S10 of the supplementary files, and the average of specific tephra correlated across the cores is presented in Tables 3, 4, 5, and 6 .

\section{Results}

The results include a description of tephra thickness (Table 1), maximum grain size (Table 2), petrography (Table S2 in the supplementary files), and trace element chemistry (averages for specific tephra in Tables 3, 4, 5, and 6; all the data for each tephra in every core in Tables S3-S10 of the supplementary files) as well as correlations of tephra among cores and source volcano identification (Table 1; Figs. 2, 3, 4, 5, 6, 7, and 8; Figs. S2-S8 in the supplementary files). To simplify the presentation of the results, each core has been subdivided into four zones which are bound by tephras from distinctive wellconstrained eruptions or eruption sequences (Fig. 2). Zone I begins at the top of the cores and extends to the tephra derived from the $4000 \pm 50$ cal years BP late Holocene $\mathrm{H} 2$ eruption of Hudson volcano (Naranjo and Stern 1998), which was identified in every core based on its thickness and petrography. Zone II consists of all the tephras between the $\mathrm{H} 2$ eruption and the sequence of 10 closely spaced tephras (S1 to S10) observed in every core. Zone III consists only of this sequence of these 10 eruptions ( $\mathrm{S} 1$ through $\mathrm{S} 10$ ), while zone IV consists of all the sediments and volcanic products below this sequence and extending back to the predominately clay- and sand-rich glacial-lacustrine sediments at the bottom of the cores. In each of these zones, groups of tephra which have similar stratigraphic relations, with relatively small separations among themselves and greater separations from the tephra in other groups, have been identified in multiple cores. These tephra groups, which have been correlated across multiple cores by both their stratigraphic relations and petrochemical characteristics, have been named A through $\mathrm{H} 2$ in zone I, I through $\mathrm{R}$ in zone II, S1 through S10 in zone III, and T through $\mathrm{Z}$ in zone IV (Figs. 2, 3, 4, 5, 6, 7, and 8; Table 1). Many of these groups have multiple tephra layers, labeled as, for example, S1 through S10. In some cases, not all the tephras in any group (for example, tephra A2 in group A or any of the U1-3 tephra) were sampled but they are labeled and included in Table 1 because they appear in multiple cores in regular stratigraphic relations with other tephras. Also, the tephra within any one group may have different sources (for example, group D; Table 1), because the different groups were identified based on their consistent internal stratigraphic relations, not their source volcanoes.

Lagos Tranquilo, El Toro, Las Mellizas, and Unco are located in the northern portion of the study area, while Espejo, Quijada, Churrasco, and Élida are further to the south (Fig. 1). A northern and southern division of the lakes (Table 1; Figs. 5, 6,7 , and 8) based on this geographic separation is useful because the cores from the northern four lakes have fewer, thinner, and finer grained deposits of Hudson-derived tephra and more frequent, somewhat thicker, and coarser deposits of Mentolat-derived tephra.

\section{Correlations and source volcano identification}

Correlation of the tephra deposits (Table 1; Figs. 2, 3, 4, 5, 6, 7, and 8; Figs. S2-S8 in the supplementary files) is based on three criteria: (1) the stratigraphic position of the tephra in the cores, (2) bulk-tephra trace element compositions (Fig. 3; Tables 2, 3, 4, and 5; Tables S3-S10 in the supplementary files), and (3) the color, morphology (Fig. 4), and abundance of their volcanic glass along with the identity and abundance of mineral microlites and phenocrysts (Table S2 in the supplementary files). Tentative identifications of the source volcanoes of tephra are also based on bulk-tephra chemistry and petrology as outlined below.

\section{Hudson tephra}

All published analyses of lavas and tephra derived from explosive eruptions of Hudson volcano, which range from basaltic to dacitic in composition, are high-abundance (HA) chemical types (Fig. 3), and thus, all tephras with HA chemistry in the cores from the lakes near Coyhaique are considered to be derived from Hudson volcano. These HA tephras (Table 1) are generally thicker and coarser grained (Table 2) in the southern lakes compared to the northern ones consistent with the location of Hudson volcano (Fig. 1). Tephras derived from previously documented explosive eruptions of Hudson also have other distinctive morphologic and petrologic characteristics used to distinguish the smaller eruptions from Hudson observed within the cores. Specifically, tephras produced by phase 2 of the H3 (1991 AD) eruption, as well as H2 and Ho tephras, are all characterized by the presence of pale orangebrown, vesicle-rich glass, which generally lacks plagioclase microlites (Fig. 4a, b). The vesicles are often highly deformed into elongated cylindrical shape reflecting the rapid extrusion of magma during these explosive eruptions. Mostly all the HA chemical types of tephras attributed to eruptions of Hudson volcano have this type of pale orange-brown, vesicle-rich tephra glass. However, a darker, vesicle-poor, microlite-rich glass also occurs in many of the tephra with HA chemistry (Fig. 4a). Mafic glasses with similar morphology are associated with phase I of both the H3 (Kratzmann et al. 2009) and 
Table 3 Average trace element concentrations ( $\mathrm{ppm}$ ) of tephras in zone I from the core top to the H2 eruption

Tephra name

\begin{tabular}{llllllllllllllllllll}
\hline A1 & B2 & $\mathrm{C} 1$ & $\mathrm{C} 2$ & $\mathrm{D} 1$ & $\mathrm{D} 2$ & $\begin{array}{l}\mathrm{D} 3= \\
\text { MAC1 }\end{array}$ & $\mathrm{E} 1$ & $\mathrm{E} 2$ & $\mathrm{E} 3$ & $\mathrm{~F} 1$ & $\mathrm{~F} 2$ & $\mathrm{~F} 3$ & $\mathrm{G} 1$ & G2 & G3 & H2
\end{tabular}

Chemical type

LAM LAF HA HA LAF HA LAM HA HA LAM HA HA HA LAM $\quad$ LAM $\quad$ LAM Source volcano

M/C/ MEN HUD HUD MEN HUD MACA HUD HUD M/C/ HUD HUD HUD M/C/MEC M/C/MEC M/C/MEC HUD MEC MEC

$n$

$\begin{array}{lllllllllllllllllllllll}1 & 3 & 4 & 3 & 1 & 2 & 7 & 2 & 7 & 1 & 7 & 1 & 1 & 7 & 2 & 3 & 10\end{array}$

\begin{tabular}{|c|c|c|c|c|c|c|c|c|c|c|c|c|c|c|c|c|c|}
\hline $\mathrm{Ti}$ & 5905 & 7069 & 9964 & 9027 & 6901 & 8503 & 6820 & 7282 & 7867 & 6888 & 9468 & 9157 & 9993 & 6617 & 5656 & 6146 & 7221 \\
\hline $\mathrm{V}$ & 97 & 299 & 287 & 241 & 334 & 307 & 222 & 258 & 256 & 386 & 261 & 274 & 348 & 234 & 221 & 232 & 146 \\
\hline $\mathrm{Cr}$ & 11 & 18 & 15 & 13 & 17 & 29 & 102 & 55 & 51 & 38 & 27 & 14 & 14 & 92 & 76 & 92 & 13 \\
\hline $\mathrm{Mn}$ & 1086 & 1452 & 1319 & 1181 & 1418 & 1220 & 1110 & 1158 & 1173 & 1395 & 1218 & 1311 & 1280 & 1037 & 1007 & 930 & 1147 \\
\hline Co & 22 & 34 & 42 & 31 & 44 & 43 & 45 & 37 & 41 & 45 & 34 & 38 & 33 & 39 & 43 & 37 & 20 \\
\hline $\mathrm{Ni}$ & 31 & 32 & 32 & 32 & 38 & 41 & 84 & 55 & 48 & 39 & 39 & 34 & 35 & 61 & 53 & 59 & 26 \\
\hline $\mathrm{Cu}$ & 73 & 71 & 70 & 126 & 86 & 136 & 92 & 98 & 78 & 127 & 98 & 46 & 133 & 85 & 66 & 97 & 55 \\
\hline $\mathrm{Zn}$ & 109 & 133 & 120 & 121 & 130 & 126 & 98 & 116 & 112 & 135 & 117 & 112 & 113 & 97 & 86 & 84 & 110 \\
\hline $\mathrm{Rb}$ & 13 & 15 & 32 & 40 & 17 & 31 & 19 & 27 & 28 & 16 & 32 & 51 & 55 & 17 & 11 & 23 & 54 \\
\hline $\mathrm{Sr}$ & 367 & 442 & 493 & 456 & 455 & 531 & 580 & 526 & 528 & 419 & 483 & 492 & 509 & 561 & 521 & 580 & 368 \\
\hline $\mathrm{Y}$ & 20 & 20 & 31 & 31 & 21 & 29 & 20 & 23 & 24 & 16 & 30 & 31 & 33 & 21 & 16 & 20 & 37 \\
\hline $\mathrm{Zr}$ & 91 & 87 & 209 & 206 & 93 & 187 & 157 & 190 & 195 & 83 & 218 & 199 & 209 & 136 & 93 & 127 & 349 \\
\hline $\mathrm{Nb}$ & 3 & 4 & 9 & 10 & 2 & 8 & 7 & 9 & 10 & 3 & 9 & 11 & 8 & 8 & 4 & 6 & 17 \\
\hline $\mathrm{Cs}$ & - & 0.4 & 0.5 & 0.7 & 0.7 & 0.7 & 0.2 & 0.6 & 0.4 & 0.8 & 0.4 & 1.2 & 1.0 & 0.2 & 0.3 & 0.5 & 0.9 \\
\hline $\mathrm{Ba}$ & 199 & 186 & 495 & 448 & 190 & 391 & 308 & 382 & 390 & 156 & 428 & 532 & 539 & 274 & 245 & 310 & 688 \\
\hline $\mathrm{La}$ & 9.1 & 8.3 & 28.5 & 28.7 & 8.5 & 23.5 & 19.5 & 24.2 & 25.1 & 6.4 & 27.3 & 28.0 & 31.6 & 17.0 & 11.8 & 17.5 & 38.7 \\
\hline $\mathrm{Ce}$ & 22.2 & 19.9 & 65.2 & 65.4 & 20.8 & 53.2 & 44.8 & 54.4 & 55.9 & 17.3 & 62.6 & 64.0 & 69.7 & 39.3 & 27.2 & 38.9 & 84.7 \\
\hline $\operatorname{Pr}$ & 2.8 & 2.7 & 8.5 & 8.3 & 2.86 & 6.8 & 5.6 & 6.7 & 6.9 & 2.2 & 8.0 & 8.3 & 9.3 & 5.0 & 3.5 & 5.0 & 10.2 \\
\hline $\mathrm{Nd}$ & 14.0 & 13.3 & 36.9 & 35.9 & 14.2 & 29.6 & 23.9 & 28.4 & 29.3 & 11.7 & 34.0 & 34.4 & 38.9 & 21.7 & 15.7 & 20.9 & 41.1 \\
\hline $\mathrm{Sm}$ & 3.96 & 3.47 & 7.61 & 7.56 & 3.41 & 6.36 & 5.00 & 5.91 & 6.05 & 2.76 & 7.32 & 7.35 & 7.94 & 4.64 & 3.50 & 4.52 & 8.59 \\
\hline $\mathrm{Eu}$ & 1.08 & 1.09 & 2.26 & 2.11 & 0.93 & 1.86 & 1.50 & 1.72 & 1.75 & 0.87 & 2.10 & 2.26 & 2.27 & 1.50 & 1.13 & 1.41 & 2.49 \\
\hline $\mathrm{Gd}$ & 4.4 & 4.2 & 8.9 & 8.8 & 4.25 & 7.5 & 5.8 & 6.7 & 6.9 & 3.7 & 8.5 & 8.5 & 9.2 & 5.3 & 4.1 & 5.3 & 10.0 \\
\hline $\mathrm{Tb}$ & 0.52 & 0.54 & 1.08 & 0.99 & 0.47 & 0.81 & 0.65 & 0.77 & 0.80 & 0.39 & 0.98 & 1.17 & 1.10 & 0.60 & 0.31 & 0.65 & 1.20 \\
\hline Dy & 3.66 & 3.41 & 6.24 & 6.08 & 3.68 & 5.18 & 3.98 & 4.58 & 4.73 & 3.03 & 5.89 & 6.20 & 6.46 & 3.77 & 3.19 & 3.83 & 6.93 \\
\hline Ho & 0.59 & 0.62 & 1.18 & 1.06 & 0.66 & 0.95 & 0.72 & 0.86 & 0.86 & 0.54 & 1.07 & 1.22 & 1.23 & 0.67 & 0.34 & 0.73 & 1.32 \\
\hline $\mathrm{Er}$ & 2.20 & 2.20 & 3.65 & 3.53 & 2.29 & 3.03 & 2.28 & 2.68 & 2.78 & 1.78 & 3.45 & 3.46 & 3.79 & 2.24 & 1.77 & 2.27 & 4.27 \\
\hline $\mathrm{Tm}$ & 0.13 & 0.20 & 0.41 & 0.38 & 0.20 & 0.32 & 0.22 & 0.32 & 0.30 & 0.18 & 0.37 & 0.43 & 0.44 & 0.21 & 0.12 & 0.26 & 0.50 \\
\hline $\mathrm{Yb}$ & 1.83 & 1.99 & 3.07 & 3.03 & 1.96 & 2.64 & 2.03 & 2.27 & 2.46 & 1.61 & 2.98 & 3.05 & 3.52 & 1.93 & 1.59 & 1.91 & 3.95 \\
\hline $\mathrm{Lu}$ & - & 0.14 & 0.32 & 0.26 & 0.21 & 0.32 & 0.17 & 0.32 & 0.26 & 0.17 & 0.29 & 0.45 & 0.48 & 0.20 & 0.12 & 0.23 & 0.49 \\
\hline Hf & 2.5 & 2.7 & 5.0 & 4.8 & 1.9 & 4.1 & 3.7 & 4.6 & 4.9 & 2.2 & 4.9 & 6.1 & 5.0 & 3.9 & 2.5 & 2.8 & 8.0 \\
\hline $\mathrm{Pb}$ & 7.0 & 5.3 & 6.9 & 8.2 & 4.8 & 6.5 & 5.3 & 6.8 & 6.9 & 5.0 & 7.1 & 7.2 & 9.0 & 4.3 & 4.1 & 4.7 & 11.2 \\
\hline Th & 1.2 & 1.9 & 3.6 & 4.3 & 0.6 & 2.9 & 2.5 & 3.9 & 4.1 & 1.1 & 3.5 & 7.0 & 4.3 & 2.8 & 1.2 & 2.3 & 6.0 \\
\hline $\mathrm{U}$ & 0.4 & 0.3 & 0.8 & 0.9 & 0.3 & 0.6 & 0.5 & 0.7 & 0.8 & 0.4 & 0.8 & 1.0 & 1.0 & 0.4 & 0.3 & 0.5 & 1.4 \\
\hline
\end{tabular}

the Ho (Weller et al. 2014) eruptions. Thus, Hudson tephra glass color and morphology are variable and the overall chemistry of tephra from Hudson eruptions varies from basaltic to dacitic, as do Hudson lavas, although all are HA chemical types (Fig. 3). Minor plagioclase feldspar, clinopyroxene, orthopyroxene, and small amounts of olivine phenocrysts are present in Hudson-derived tephra deposits, but not amphibole (Table S2 in the supplementary files). 
Table 4 Average trace element compositions ( $\mathrm{ppm}$ ) of tephras in zone II from the H2 eruption to the top of the sequence of tephras S1-10

Tephra name

\begin{tabular}{lllllllllllllllll}
\hline $\mathrm{I}$ & $\mathrm{J}$ & $\mathrm{K}$ & $\mathrm{Ls}$ & $\mathrm{Ln}$ & $\mathrm{M}$ & $\mathrm{N}$ & $\mathrm{O} 1$ & $\mathrm{O} 2$ & $\mathrm{P} 1$ & $\mathrm{P} 2$ & Q1 & Q2 & MEN1 & $\mathrm{R}$
\end{tabular}

Chemical type

HA HA HA LAM LAF HA HA LAF LAM LAM $\quad$ HA $\quad$ LAF LAF LAF

Source volcano

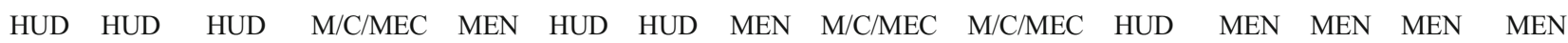

\begin{tabular}{|c|c|c|c|c|c|c|c|c|c|c|c|c|c|c|c|}
\hline & 3 & 4 & 3 & 2 & 3 & 3 & 9 & 1 & 5 & 8 & 5 & 3 & 2 & 7 & 3 \\
\hline $\mathrm{Ti}$ & 8084 & 10,010 & 10,342 & 6830 & 6639 & 7813 & 8304 & 6627 & 6230 & 6524 & 15,661 & 5478 & 5875 & 4761 & 6199 \\
\hline V & 172 & 306 & 282 & 339 & 224 & 165 & 170 & 157 & 204 & 213 & 321 & 190 & 176 & 185 & 249 \\
\hline $\mathrm{Cr}$ & 9 & 16 & 16 & 25 & 23 & 18 & 23 & 56 & 18 & 22 & 13 & 16 & 18 & 22 & 18 \\
\hline $\mathrm{Mn}$ & 1292 & 1236 & 1171 & 1160 & 1077 & 1126 & 1246 & 1162 & 1078 & 1122 & 1596 & 1092 & 1175 & 1607 & 1364 \\
\hline $\mathrm{Co}$ & 22 & 33 & 29 & 37 & 28 & 20 & 33 & 71 & 29 & 34 & 36 & 27 & 29 & 34 & 33 \\
\hline $\mathrm{Ni}$ & 30 & 34 & 36 & 36 & 38 & 35 & 38 & 46 & 32 & 35 & 39 & 34 & 34 & 30 & 37 \\
\hline $\mathrm{Cu}$ & 74 & 108 & 85 & 127 & 79 & 97 & 66 & 78 & 69 & 91 & 103 & 120 & 48 & 22 & 40 \\
\hline $\mathrm{Zn}$ & 125 & 123 & 123 & 110 & 118 & 114 & 121 & 116 & 107 & 115 & 145 & 117 & 114 & 117 & 119 \\
\hline $\mathrm{Rb}$ & 57 & 30 & 38 & 18 & 28 & 55 & 46 & 22 & 17 & 16 & 24 & 19 & 16 & 7 & 17 \\
\hline $\mathrm{Sr}$ & 385 & 521 & 484 & 447 & 474 & 360 & 397 & 378 & 452 & 452 & 450 & 409 & 472 & 556 & 528 \\
\hline $\mathrm{Y}$ & 39 & 30 & 32 & 21 & 23 & 42 & 39 & 28 & 21 & 20 & 38 & 22 & 20 & 12 & 19 \\
\hline $\mathrm{Zr}$ & 343 & 222 & 207 & 83 & 128 & 388 & 346 & 108 & 86 & 78 & 201 & 104 & 84 & 49 & 86 \\
\hline $\mathrm{Nb}$ & 16 & 13 & 11 & 2 & 4 & 17 & 16 & 5 & 4 & 4 & 9 & 4 & 3 & 2 & 3 \\
\hline Cs & 1.2 & 0.5 & 0.9 & 0.9 & 0.5 & 1.3 & 0.8 & 0.4 & 0.5 & 0.5 & 0.5 & 0.9 & 0.4 & 0.2 & 0.5 \\
\hline $\mathrm{Ba}$ & 661 & 459 & 473 & 197 & 334 & 649 & 612 & 289 & 229 & 224 & 337 & 231 & 218 & 113 & 223 \\
\hline $\mathrm{La}$ & 39.0 & 30.8 & 32.1 & 9.5 & 15.4 & 42.0 & 38.2 & 14.1 & 9.6 & 9.5 & 26.2 & 11.1 & 9.3 & 5.5 & 10.6 \\
\hline $\mathrm{Ce}$ & 85.4 & 69.3 & 70.0 & 21.7 & 36.1 & 93.0 & 85.7 & 32.5 & 22.9 & 22.8 & 63.6 & 25.5 & 22.3 & 13.7 & 24.8 \\
\hline $\operatorname{Pr}$ & 10.31 & 8.88 & 9.11 & 3.08 & 4.66 & 11.4 & 10.62 & 4.3 & 3.08 & 3.12 & 8.69 & 3.47 & 2.92 & 1.87 & 3.19 \\
\hline $\mathrm{Nd}$ & 42.2 & 36.2 & 37.0 & 13.8 & 21.5 & 45.6 & 42.4 & 20.3 & 14.5 & 14.0 & 39.5 & 16.0 & 14.0 & 9.0 & 14.9 \\
\hline $\mathrm{Sm}$ & 8.49 & 7.65 & 7.92 & 3.59 & 4.88 & 9.44 & 8.94 & 4.82 & 3.73 & 3.69 & 8.72 & 3.77 & 3.68 & 2.16 & 3.69 \\
\hline $\mathrm{Eu}$ & 2.35 & 2.20 & 2.27 & 1.14 & 1.35 & 2.51 & 2.53 & 1.54 & 1.17 & 1.23 & 2.69 & 1.21 & 1.08 & 0.88 & 1.21 \\
\hline $\mathrm{Gd}$ & 9.64 & 8.90 & 9.13 & 4.47 & 5.75 & 10.5 & 10.12 & 6.0 & 4.45 & 4.43 & 10.25 & 4.59 & 4.45 & 2.70 & 4.30 \\
\hline $\mathrm{Tb}$ & 1.16 & 1.03 & 1.11 & 0.57 & 0.65 & 1.35 & 1.26 & 0.69 & 0.56 & 0.57 & 1.29 & 0.52 & 0.50 & 0.31 & 0.50 \\
\hline Dy & 6.88 & 5.82 & 6.12 & 3.77 & 4.36 & 7.56 & 7.35 & 4.74 & 3.71 & 3.71 & 7.23 & 3.62 & 3.56 & 2.21 & 3.61 \\
\hline Но & 1.33 & 1.08 & 1.19 & 0.75 & 0.75 & 1.52 & 1.39 & 0.92 & 0.67 & 0.74 & 1.37 & 0.67 & 0.62 & 0.35 & 0.65 \\
\hline $\mathrm{Er}$ & 4.21 & 3.37 & 3.75 & 2.27 & 2.61 & 4.77 & 4.39 & 2.93 & 2.28 & 2.22 & 4.18 & 2.25 & 2.42 & 1.32 & 2.12 \\
\hline $\mathrm{Tm}$ & 0.53 & 0.38 & 0.46 & 0.26 & 0.19 & 0.63 & 0.55 & 0.31 & 0.21 & 0.28 & 0.50 & 0.24 & 0.20 & 0.14 & 0.21 \\
\hline $\mathrm{Yb}$ & 3.82 & 2.95 & 3.16 & 2.02 & 2.35 & 4.41 & 4.15 & 2.79 & 1.99 & 2.11 & 3.52 & 2.07 & 2.02 & 1.25 & 1.95 \\
\hline $\mathrm{Lu}$ & 0.53 & 0.30 & 0.43 & 0.28 & 0.18 & 0.67 & 0.53 & 0.31 & 0.14 & 0.24 & 0.46 & 0.25 & 0.10 & 0.09 & 0.21 \\
\hline Hf & 7.1 & 5.6 & 5.0 & 2.0 & 3.0 & 8.5 & 7.7 & 2.8 & 2.4 & 2.6 & 4.5 & 2.7 & 2.1 & 1.4 & 2.1 \\
\hline $\mathrm{Pb}$ & 10.1 & 8.0 & 7.8 & 5.9 & 7.0 & 12.6 & 10.5 & 9.1 & 6.7 & 6.8 & 5.6 & 8.0 & 6.2 & 3.2 & 5.9 \\
\hline $\mathrm{Th}$ & 5.2 & 3.9 & 4.6 & 1.1 & 2.2 & 6.2 & 5.2 & 2.3 & 1.4 & 1.9 & 2.6 & 1.8 & 1.1 & 0.6 & 1.2 \\
\hline $\mathrm{U}$ & 1.4 & 0.8 & 1.0 & 0.5 & 0.7 & 1.5 & 1.2 & 0.6 & 0.5 & 0.4 & 0.6 & 0.5 & 0.4 & 0.1 & 0.4 \\
\hline
\end{tabular}

\section{Mentolat tephra}

In contrast, Mentolat lavas (López-Escobar et al. 1993) and MEN1 tephra (Naranjo and Stern 2004; Stern et al. 2013, 2015a, b) are low-abundance (LA) chemical types (Fig. 3), with relatively low LIL $(\mathrm{K}, \mathrm{Rb}, \mathrm{Ba})$ for intermediate ( $\mathrm{Ti}$
$<6000$ ppm; Fig. 3) compositions compared to even other LA-type basalts (López-Escobar et al. 1993; Naranjo and Stern 2004; Watt et al. 2011). MEN1 tephra is characterized by the presence of colorless rhyolitic (Stern et al. 2015b) glass with abundant circular undeformed vesicles and no mineral microlites (Fig. 4c, d). Other tephras in the cores with LA 
Table 5 Average trace element concentrations (ppm) of the S1-10 tephra in zone III

Tephra name

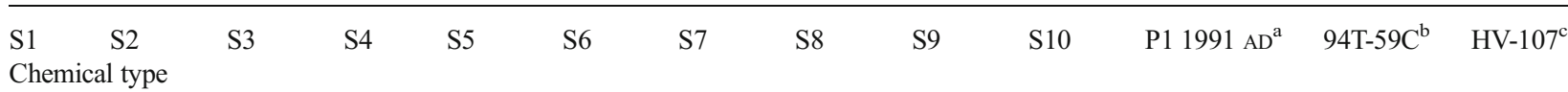

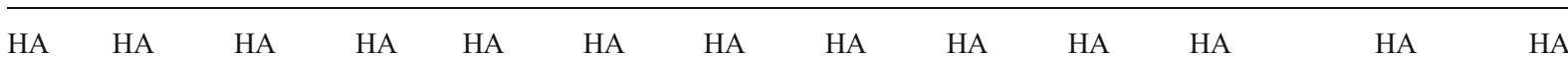

Source volcano

HUD HUD HUD HUD HUD HUD HUD HUD HUD HUD HUD $\quad$ HUD

\begin{tabular}{|c|c|c|c|c|c|c|c|c|c|c|c|c|c|}
\hline & 4 & 10 & 4 & 7 & 8 & 1 & 1 & 3 & 1 & 1 & 2 & 1 & 1 \\
\hline $\mathrm{Ti}$ & 9976 & 10,692 & 10,406 & 7542 & 11,515 & 11,097 & 12,689 & 12,668 & 12,702 & 13,528 & 12,529 & 10,502 & 11,810 \\
\hline V & 237 & 253 & 261 & 102 & 253 & 288 & 285 & 291 & 301 & 280 & 331 & - & 258 \\
\hline $\mathrm{Cr}$ & 23 & 19 & 18 & 6 & 17 & 25 & 18 & 17 & 27 & 19 & 26 & - & 52 \\
\hline $\mathrm{Mn}$ & 1302 & 1326 & 1326 & 1320 & 1413 & 1395 & 1487 & 1540 & 1461 & 1431 & 1472 & 1242 & 1394 \\
\hline Co & 37 & 38 & 35 & 36 & 32 & 36 & 30 & 38 & 49 & 51 & 32 & - & 20 \\
\hline $\mathrm{Ni}$ & 34 & 30 & 30 & 20 & 30 & 46 & 27 & 37 & 49 & 25 & 12 & - & 3 \\
\hline $\mathrm{Cu}$ & 89 & 111 & 93 & 91 & 90 & 49 & 86 & 77 & 56 & 77 & 48 & - & 27 \\
\hline $\mathrm{Zn}$ & 122 & 120 & 121 & 123 & 125 & 122 & 126 & 125 & 135 & 117 & 104 & - & - \\
\hline $\mathrm{Rb}$ & 27 & 26 & 23 & 51 & 23 & 26 & 23 & 19 & 25 & 24 & 30 & 29 & 33 \\
\hline $\mathrm{Sr}$ & 540 & 552 & 540 & 332 & 558 & 575 & 580 & 571 & 625 & 586 & 535 & 578 & 504 \\
\hline $\mathrm{Y}$ & 31 & 35 & 35 & 45 & 37 & 36 & 40 & 38 & 38 & 41 & 37 & 28 & 40 \\
\hline $\mathrm{Zr}$ & 233 & 252 & 256 & 418 & 263 & 263 & 268 & 266 & 255 & 229 & 183 & 194 & 228 \\
\hline $\mathrm{Nb}$ & 14 & 13 & 13 & 20 & 15 & 12 & 13 & 11 & 11 & 12 & 8 & 9 & 10 \\
\hline $\mathrm{Cs}$ & 0.3 & 0.6 & 0.5 & 0.8 & 0.4 & 0.8 & 0.5 & 0.3 & 0.8 & 0.5 & - & 0.7 & 1 \\
\hline $\mathrm{Ba}$ & 523 & 578 & 511 & 674 & 486 & 457 & 449 & 434 & 548 & 421 & 405 & 405 & 466 \\
\hline $\mathrm{La}$ & 32.9 & 34.2 & 34.0 & 42.1 & 34.6 & 32.7 & 36.5 & 35.2 & 36.7 & 35.0 & - & 29.2 & 30.1 \\
\hline $\mathrm{Ce}$ & 75.2 & 78.9 & 78.7 & 95.0 & 80.7 & 76.1 & 86.3 & 84.7 & 84.5 & 80.5 & - & 62.8 & 71.0 \\
\hline $\operatorname{Pr}$ & 9.47 & 10.09 & 10.07 & 11.57 & 10.53 & 9.84 & 10.91 & 10.99 & 10.9 & 10.8 & - & 8.16 & 9.50 \\
\hline $\mathrm{Nd}$ & 40.8 & 42.1 & 42.2 & 46.9 & 44.4 & 41.3 & 48.0 & 47.1 & 49.2 & 46.5 & - & 33.4 & 40.0 \\
\hline $\mathrm{Sm}$ & 8.32 & 8.81 & 8.77 & 9.78 & 9.25 & 8.92 & 10.01 & 9.84 & 9.78 & 9.81 & - & 7.04 & 8.60 \\
\hline $\mathrm{Eu}$ & 2.47 & 2.59 & 2.56 & 2.73 & 2.71 & 2.69 & 2.93 & 2.92 & 3.04 & 2.97 & - & 1.99 & 2.71 \\
\hline $\mathrm{Gd}$ & 9.05 & 9.61 & 9.68 & 10.75 & 10.19 & 10.12 & 10.45 & 12.08 & 11.02 & 10.6 & - & 8.03 & 8.20 \\
\hline $\mathrm{Tb}$ & 1.08 & 1.21 & 1.24 & 1.41 & 1.30 & 1.29 & 1.38 & 1.38 & 1.35 & 1.37 & - & 0.95 & 1.23 \\
\hline Dy & 6.31 & 6.71 & 6.64 & 8.22 & 7.05 & 7.26 & 7.71 & 7.52 & 7.50 & 7.38 & - & 5.58 & 7.30 \\
\hline Но & 1.13 & 1.27 & 1.27 & 1.62 & 1.34 & 1.27 & 1.51 & 1.36 & 1.40 & 1.46 & - & 1.04 & 1.55 \\
\hline $\mathrm{Er}$ & 3.54 & 3.85 & 3.89 & 4.98 & 4.07 & 3.86 & 4.33 & 4.14 & 4.39 & 4.12 & - & 3.40 & 4.00 \\
\hline $\mathrm{Tm}$ & 0.36 & 0.48 & 0.47 & 0.69 & 0.53 & 0.48 & 0.57 & 0.51 & 0.55 & 0.54 & - & 0.38 & 0.59 \\
\hline $\mathrm{Yb}$ & 3.01 & 3.39 & 3.35 & 4.81 & 3.48 & 3.32 & 3.42 & 3.58 & 3.65 & 3.54 & - & 2.90 & 3.60 \\
\hline $\mathrm{Lu}$ & 0.23 & 0.44 & 0.37 & 0.70 & 0.45 & 0.53 & 0.55 & 0.48 & 0.52 & 0.56 & - & 0.39 & 0.55 \\
\hline Hf & 5.4 & 5.6 & 5.7 & 9.4 & 6.5 & 5.5 & 5.7 & 5.7 & 5.5 & 5.0 & - & 4.5 & 5.4 \\
\hline $\mathrm{Pb}$ & 10.8 & 6.2 & 6.4 & 11.5 & 6.0 & 7.4 & 4.3 & 6.0 & 7.2 & 4.5 & - & 7.1 & 7.0 \\
\hline Th & 4.7 & 3.6 & 3.8 & 7.8 & 4.4 & 3.5 & 4.1 & 3.1 & 3.8 & 4.5 & - & 5.5 & 3.70 \\
\hline $\mathrm{U}$ & 0.6 & 0.7 & 0.6 & 1.6 & 0.7 & 0.7 & 0.8 & 0.6 & 0.7 & 0.7 & - & 1.0 & 0.90 \\
\hline
\end{tabular}

${ }^{a}$ From Kratzmann et al. (2009, 2010)

${ }^{\mathrm{b}}$ From Naranjo and Stern (1998)

${ }^{\mathrm{c}}$ From Gutiérrez et al. (2005)

character and containing clear colorless glass are referred to as low-abundance felsic (LAF) petrochemical types and interpreted as being derived from Mentolat volcano. However, the MEN1 eruption, like those of Hudson, as well as Melimoyu MEL1 and Chaiten CHA1 further north in the SSVZ (Naranjo and Stern 2004), was also heterogeneous, 
Table 6 Average trace element compositions ( $\mathrm{ppm}$ ) of the tephras in zone IV from the bottom of the S1-10 sequence to the bottom of the core

\begin{tabular}{|c|c|c|c|c|c|c|c|c|c|c|c|c|c|}
\hline \multicolumn{14}{|c|}{ Tephra name } \\
\hline & $\begin{array}{l}\mathrm{T} \\
\text { Chemi }\end{array}$ & $\begin{array}{l}\mathrm{V} \\
\text { al type }\end{array}$ & Ws & Wn & $\mathrm{X} 1$ & $\mathrm{X} 2$ & $\mathrm{X} 3$ & Y1 & $\mathrm{Z1}$ & H0 & $\mathrm{Z3}$ & MEN0 & $\mathrm{Z} 5$ \\
\hline & $\begin{array}{l}\text { LAF } \\
\text { Source }\end{array}$ & $\begin{array}{l}\text { HA } \\
\text { volcano }\end{array}$ & HA & LAM & HA & HA & HA & LAM & HA & HA & LAM & LAF & LAM \\
\hline & $\begin{array}{l}\text { MEN } \\
n\end{array}$ & HUD & HUD & $\mathrm{M} / \mathrm{C} / \mathrm{MEC}$ & HUD & HUD & HUD & $\mathrm{M} / \mathrm{C} / \mathrm{MEC}$ & HUD & HUD & $\mathrm{M} / \mathrm{C} / \mathrm{MEC}$ & MEN & $\mathrm{M} / \mathrm{C} / \mathrm{MEC}$ \\
\hline & 8 & 11 & 1 & 2 & 1 & 4 & 7 & 5 & 16 & 22 & 7 & 7 & 4 \\
\hline $\mathrm{Ti}$ & 6228 & 12,266 & 12,586 & 5807 & 12,557 & 11,568 & 10,794 & 6740 & 9846 & 8350 & 6091 & 4728 & 5864 \\
\hline $\mathrm{V}$ & 161 & 311 & 256 & 260 & 246 & 245 & 229 & 261 & 306 & 208 & 236 & 208 & 245 \\
\hline $\mathrm{Cr}$ & 14 & 16 & 9 & 24 & 9 & 7 & 11 & 18 & 35 & 18 & 9 & 21 & 22 \\
\hline $\mathrm{Mn}$ & 1104 & 1272 & 1487 & 873 & 1369 & 1331 & 1294 & 1153 & 1179 & 1134 & 1067 & 1030 & 1146 \\
\hline $\mathrm{Co}$ & 47 & 38 & 81 & 35 & 21 & 26 & 38 & 35 & 38 & 33 & 28 & 30 & 29 \\
\hline $\mathrm{Ni}$ & 20 & 27 & 39 & 26 & 19 & 15 & 19 & 21 & 29 & 25 & 20 & 24 & 29 \\
\hline $\mathrm{Cu}$ & 137 & 133 & 43 & 325 & 143 & 102 & 81 & 125 & 108 & 231 & 119 & 69 & 125 \\
\hline $\mathrm{Zn}$ & 118 & 122 & 131 & 98 & 122 & 121 & 119 & 110 & 108 & 108 & 101 & 87 & 110 \\
\hline $\mathrm{Rb}$ & 29 & 30 & 40 & 16 & 33 & 32 & 34 & 21 & 30 & 41 & 19 & 23 & 29 \\
\hline $\mathrm{Sr}$ & 377 & 471 & 486 & 443 & 462 & 462 & 444 & 470 & 478 & 451 & 475 & 411 & 446 \\
\hline $\mathrm{Y}$ & 26 & 36 & 44 & 17 & 42 & 41 & 37 & 23 & 29 & 31 & 20 & 16 & 21 \\
\hline $\mathrm{Zr}$ & 128 & 231 & 298 & 69 & 270 & 268 & 260 & 99 & 183 & 226 & 79 & 73 & 78 \\
\hline $\mathrm{Nb}$ & 5 & 11 & 12 & 2 & 10 & 12 & 11 & 4 & 9 & 13 & 4 & 3 & 3 \\
\hline Cs & 1.3 & 0.5 & 1.3 & 0.4 & 0.8 & 0.8 & 0.6 & 1.0 & 0.8 & 1.1 & 0.9 & 1.4 & 1.6 \\
\hline $\mathrm{Ba}$ & 310 & 437 & 515 & 199 & 438 & 437 & 454 & 259 & 386 & 514 & 242 & 206 & 277 \\
\hline $\mathrm{La}$ & 13.7 & 30.1 & 32.6 & 9.8 & 31.1 & 30.2 & 30.3 & 12.8 & 23.6 & 28.6 & 9.5 & 8.4 & 11.2 \\
\hline $\mathrm{Ce}$ & 32.6 & 70.3 & 77.1 & 22.2 & 73.3 & 70.7 & 70.4 & 29.4 & 53.8 & 63.4 & 22.3 & 19.1 & 25.4 \\
\hline $\operatorname{Pr}$ & 4.3 & 9.2 & 10.3 & 2.9 & 9.7 & 9.5 & 9.0 & 3.9 & 6.9 & 7.9 & 3.0 & 2.5 & 3.3 \\
\hline $\mathrm{Nd}$ & 19.4 & 39.8 & 45.1 & 12.9 & 42.4 & 40.4 & 39.1 & 17.4 & 29.4 & 33.1 & 14.2 & 11.2 & 15.0 \\
\hline $\mathrm{Sm}$ & 4.97 & 8.80 & 9.88 & 3.30 & 9.25 & 8.97 & 8.57 & 4.29 & 6.51 & 7.19 & 3.69 & 2.83 & 3.78 \\
\hline $\mathrm{Eu}$ & 1.55 & 2.68 & 2.97 & 1.10 & 2.79 & 2.80 & 2.58 & 1.39 & 2.07 & 2.17 & 1.28 & 0.98 & 1.25 \\
\hline $\mathrm{Gd}$ & 5.92 & 10.19 & 11.15 & 4.12 & 10.0 & 10.05 & 9.98 & 5.13 & 7.56 & 8.23 & 4.41 & 3.36 & 4.70 \\
\hline $\mathrm{Tb}$ & 0.80 & 1.29 & 1.46 & 0.52 & 1.37 & 1.37 & 1.24 & 0.70 & 0.98 & 1.04 & 0.59 & 0.38 & 0.58 \\
\hline Dy & 4.81 & 6.95 & 8.32 & 3.18 & 7.86 & 7.53 & 6.98 & 4.12 & 5.49 & 5.82 & 3.74 & 2.77 & 3.64 \\
\hline Но & 0.94 & 1.32 & 1.64 & 0.57 & 1.57 & 1.50 & 1.32 & 0.83 & 1.07 & 1.12 & 0.72 & 0.54 & 0.70 \\
\hline Er & 2.96 & 4.07 & 4.91 & 1.90 & 4.63 & 4.39 & 4.16 & 2.52 & 3.29 & 3.43 & 2.27 & 1.79 & 2.28 \\
\hline $\mathrm{Tm}$ & 0.35 & 0.50 & 0.62 & 0.12 & 0.57 & 0.57 & 0.51 & 0.30 & 0.41 & 0.41 & 0.29 & 0.19 & 0.24 \\
\hline $\mathrm{Yb}$ & 2.74 & 3.46 & 3.96 & 1.80 & 4.19 & 3.99 & 3.59 & 2.26 & 2.88 & 3.09 & 2.06 & 1.65 & 2.06 \\
\hline $\mathrm{Lu}$ & 0.33 & 0.48 & 0.66 & 0.13 & 0.58 & 0.58 & 0.51 & 0.29 & 0.40 & 0.39 & 0.29 & 0.20 & 0.22 \\
\hline Hf & 3.7 & 5.5 & 6.5 & 2.0 & 5.8 & 6.7 & 5.9 & 2.8 & 4.4 & 5.6 & 2.6 & 2.2 & 2.3 \\
\hline $\mathrm{Pb}$ & 9.6 & 6.9 & 8.8 & 8.1 & 5.5 & 6.2 & 6.9 & 7.3 & 5.6 & 8.5 & 5.8 & 6.2 & 9.1 \\
\hline Th & 3.2 & 3.5 & 4.4 & 2.0 & 3.7 & 4.7 & 4.4 & 2.9 & 4.0 & 5.3 & 2.1 & 2.2 & 2.7 \\
\hline $\mathrm{U}$ & 0.9 & 0.7 & 0.9 & 0.5 & 1.0 & 0.9 & 0.9 & 0.7 & 0.8 & 1.2 & 0.6 & 0.8 & 1.3 \\
\hline
\end{tabular}

grading upwards in proximal outcrops into a more mafic composition, so that a darker, vesicle-poor, microlite-rich glass also occurs in this and other LAF-type tephras. These other LAF chemical-type tephra layers, interpreted to have been produced by Mentolat (Table 1), which are thicker and more frequent in the northern lakes, have, as does MEN1 tephra, abundant plagioclase, clinopyroxene, and highly pleochroic orthopyroxene (hypersthene) phenocrysts (Fig. 4c), minor olivine, along with variable amounts of dark brown amphibole and, in two cases (tephras O1 and R), biotite. López-Escobar et al. (1993) also recognized biotite in one Mentolat lava sample. 


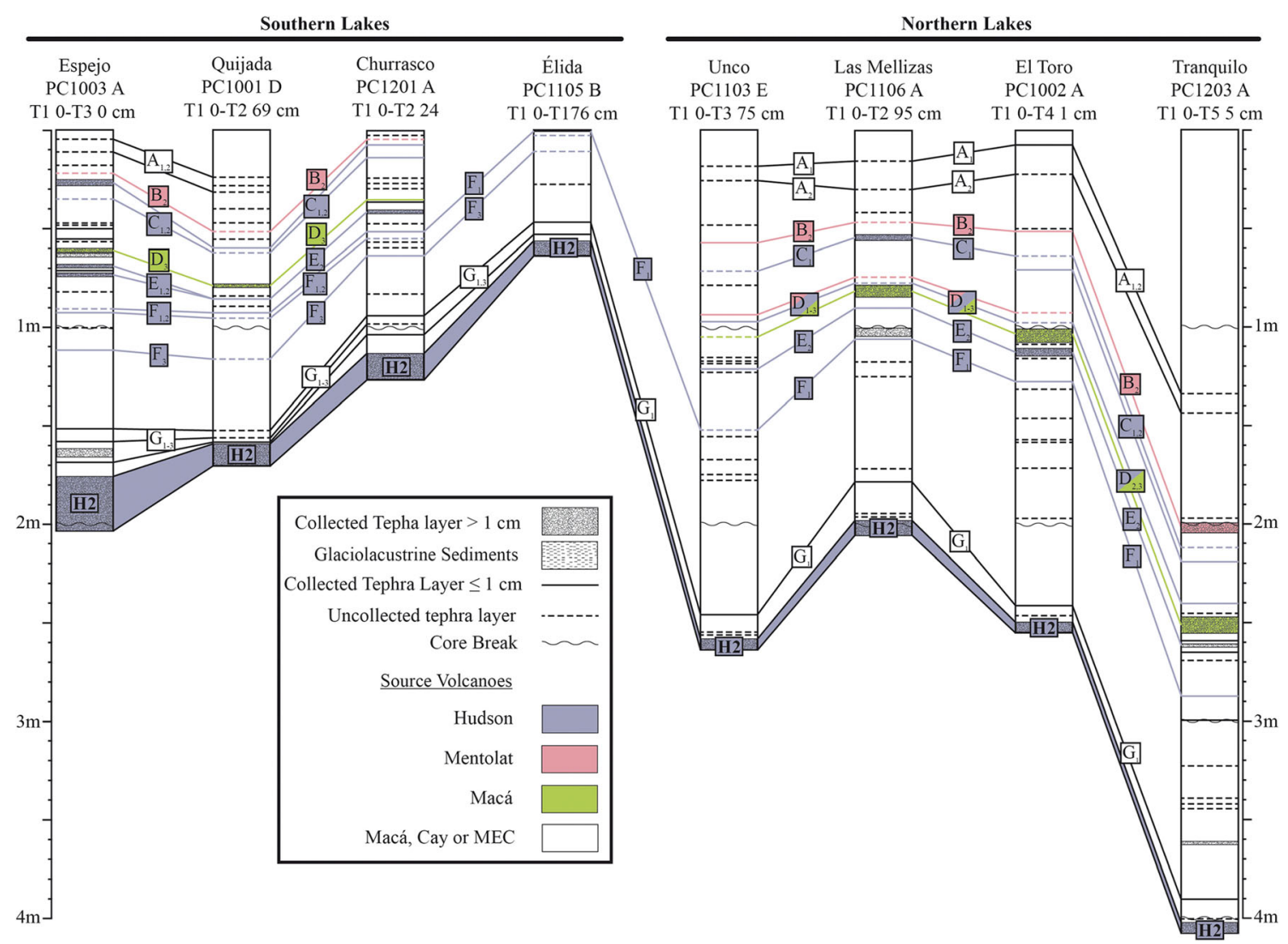

Fig. 5 Stratigraphic sections for the eight lake cores for zone I, from the top of the cores to the H2 Hudson tephra, showing the correlations for tephras A to H2 (Table 1) among the different cores

\section{Macá, Cay, and MEC-derived tephra}

Many of the tephra deposits within the sediment cores are LA chemical types but are petrographically distinct from Mentolat tephras. These have dark brown to black glass with low to moderate vesicle abundances and often high abundances of microlites but lack any clear vesicle-rich glass (Fig. 4e, f). The most abundant mineral phenocryst is plagioclase with minor clinopyroxene, orthopyroxene, and trace olivine. Amphibole is absent. These tephras with LA character with dark glass, but no clear glass or amphibole, which are referred to as lowabundance mafic (LAM) petrochemical types, are chemically and petrologically similar to MAC1 tephra derived from Macá volcano (Naranjo and Stern 2004), but they may also have been derived from Cay volcano or one of the many small Holocene minor monogenetic eruptive centers (MECs) in the region, which both also erupted LAM-type magmas. These tephras are not assigned specifically to one of these possible sources, with the exception of one tephra in group D (D3) which is correlated directly with MAC1 (Table 1).

\section{General}

An important point is that for these lake deposits, no internal eruption-related lithostratigraphic variations have been observed within individual tephra layers, even for the thickest deposits such as Ho (Weller et al. 2014) and H2. This is because deposition of the tephra from the air to the bottom of even these small lakes involves processes of mixing and homogenization such as settling, bioturbation, or lake currents that eliminate the stratigraphic segregation of sequentially variable eruptive phases often preserved in outcrop deposits of tephra airfall (Bertrand et al. 2014). The bulk tephras in the cores represent the end product of these mixing processes that, we suggest, are likely to have been generally similar in all the spatially related small lakes from which the tephras have been sampled, thus rendering the chemical compositions of the bulk tephra comparable. For this reason, we consider the approach of comparing bulk trace element chemical analysis of tephra from different cores to be a useful technique for correlation of the tephra among the cores in this relatively restricted area of Southern Chile, despite the fact that it is clear that all the tephras are heterogeneous mixtures of mineral grains and glasses of variable compositions that may be mechanically separated in different proportions during deposition, thus affecting the final bulk composition of the tephra. Nevertheless, the trace element data (Tables 3, 4, 5, and 6) preserve the high abundance compared to low abundance characteristics of tephra associated with the specific petrographic features described above, such as, for example, amphibole and clear glass 


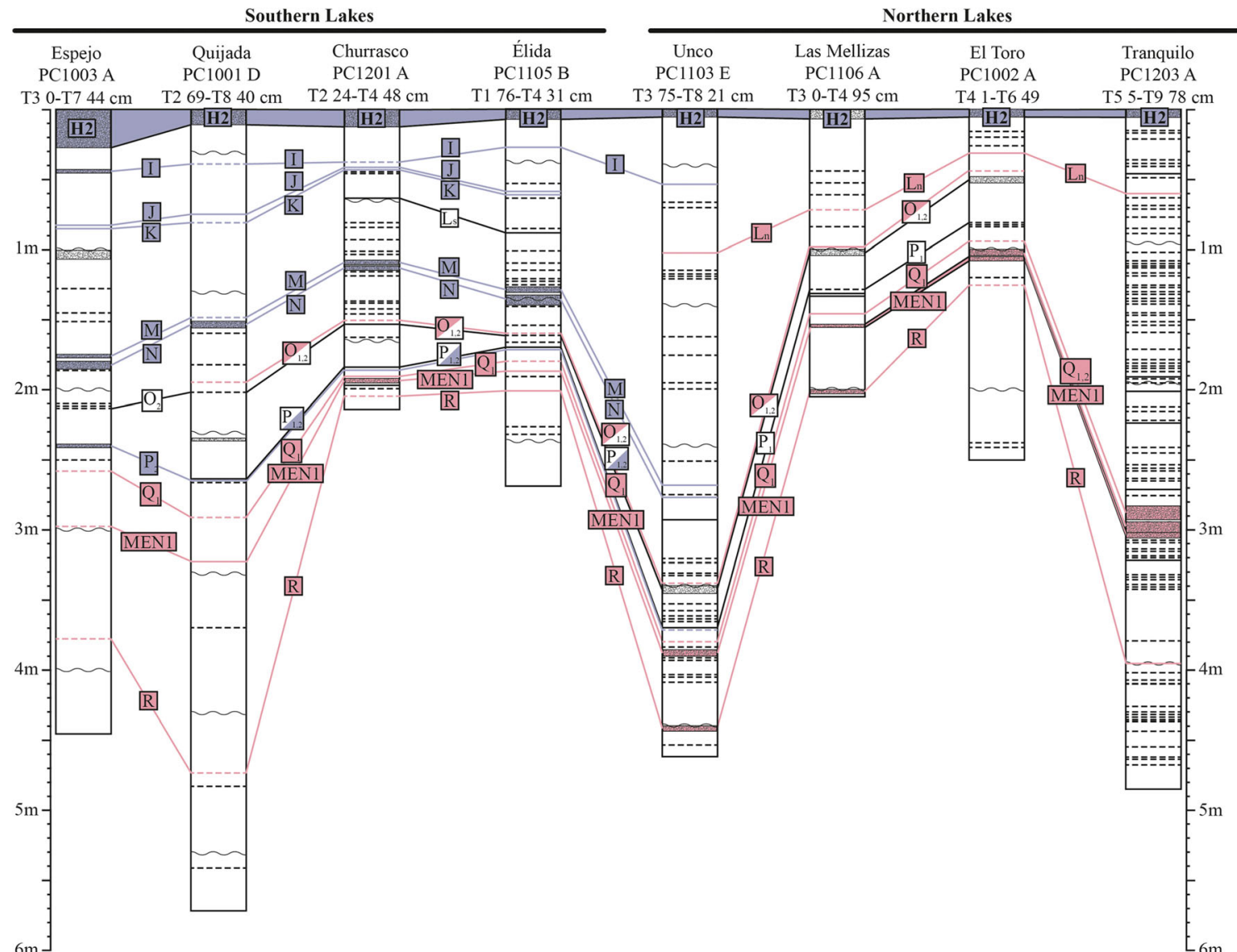

Fig. 6 Stratigraphic sections for the eight lake cores for zone II, from the H2 Hudson tephra to the top of the S1-10 sequence of tephra, showing the correlations from tephras $\mathrm{H} 2$ to $\mathrm{R}$ among the different cores

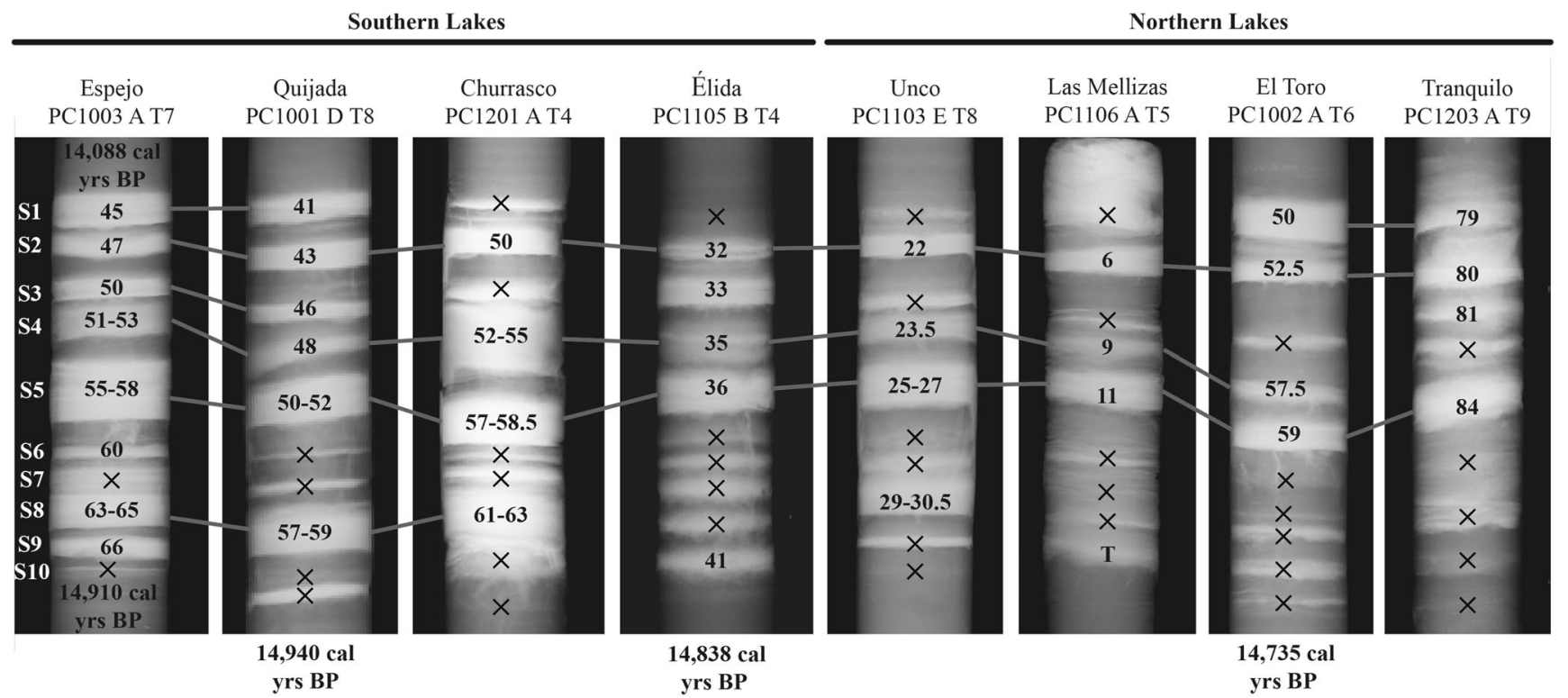

Fig. 7 Images of zone III, the S1-10 sequence of closely spaced eruptions within the eight lake cores. The analyzed samples are marked with the depth from the top of the indicated core section and the unsampled tephra are marked with an $X$. Some images were stretched in order to line up the correlated tephras, but all cores are $4 \mathrm{~cm}$ wide, and the depth in centimeters to each layer provides a measure of the actual vertical scale for each image. All deposits within the sequence are HA

chemical types derived from Hudson. The S4 tephra contains light brown glass with elongated vesicles, and lower $\mathrm{Ti}$ and $\mathrm{Sr}$ and higher $\mathrm{Rb}, \mathrm{Ba}, \mathrm{Zr}$, and La contents, and is clearly more intermediate in composition that the other nine tephras, which all contain dark brown glass with few spherical vesicles and abundant mineral microlites. Radiocarbon dates are labeled in their respective cores (Table S2 in the supplementary data repository; Miranda et al. 2013) 

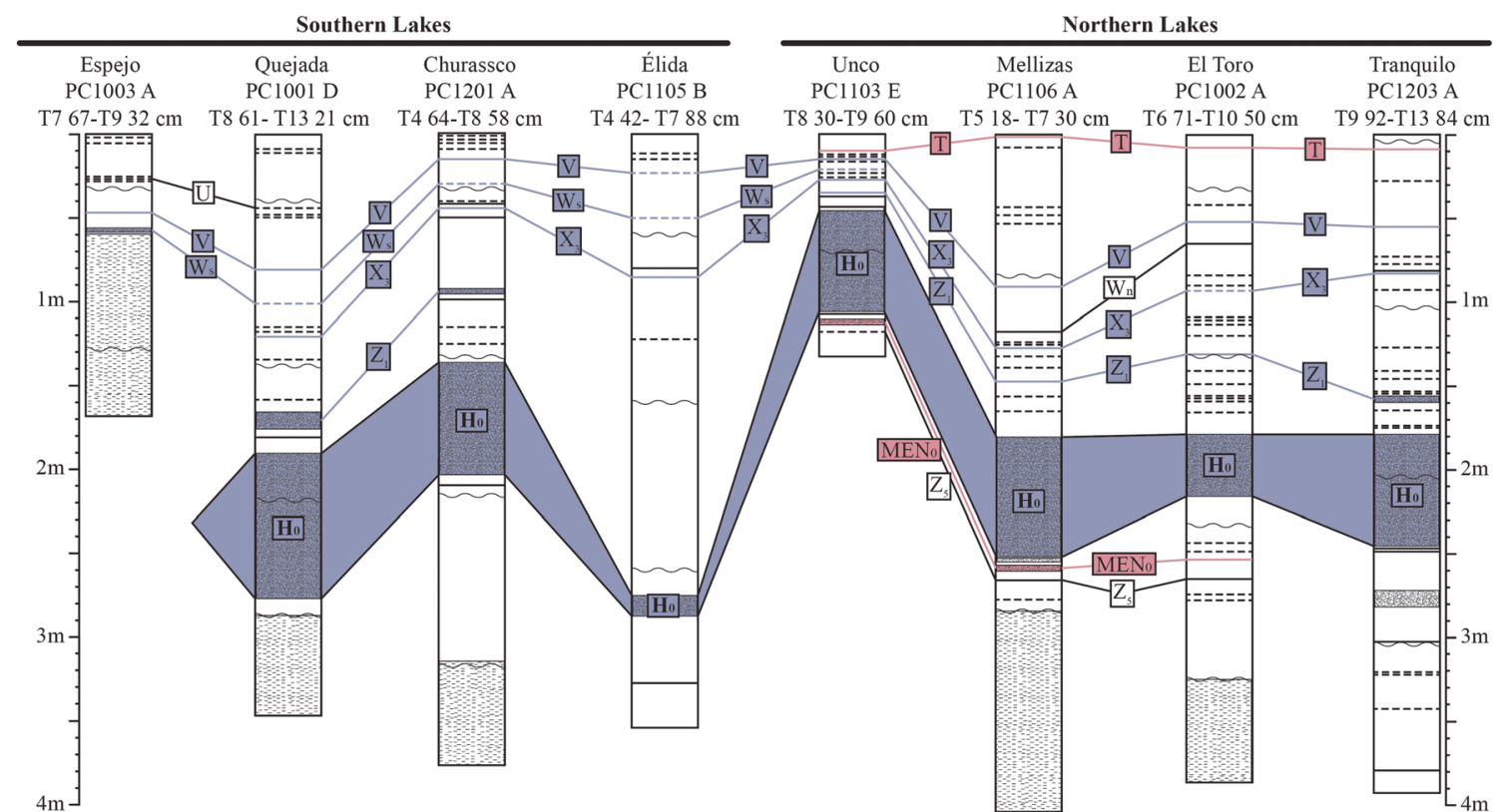

Fig. 8 Stratigraphic sections for the eight lakes for zone IV, from the S110 sequence of tephra to the base of the cores which generally occurs where, predominately, organic matter-rich lake sediments end and

glaciolacustrine clay-rich sediments begin. Shown are the correlations of tephras $\mathrm{T}$ through $\mathrm{Z}$ which include the large Late Glacial Ho eruption from Hudson (Weller et al. 2014)

in the LAF-type tephra interpreted to have been derived from Mentolat (Fig. 4c, d) and stretched-vesicle-rich, pale brown, microlite-free glasses in the HA-type tephra interpreted to have been derived from Hudson volcano (Fig. 4a, b).

\section{Zone I: core tops to $\mathbf{H} 2$}

\section{Tephra group A}

Tephra group A consists of two thin deposits, a few centimeters apart, each recognized in two of the southern cores and four of the northern cores (Table 1). Tephra A1 has a LAMtype chemical composition. It consists of blocky black to dark brown glass with minor small spherical vesicles and high abundance of plagioclase microlites. Plagioclase phenocrysts are common in this tephra. Based on its chemistry and petrography, its source volcano may be either Macá or Cay or one of the MECs. No samples of A2 were taken from any of the cores.

\section{Tephra group B}

Tephra group B consists of two thin deposits in three of the southern cores and thicker (up to $4 \mathrm{~cm}$ ) layers in the northern lakes (Table 1). No samples of tephra B1 were taken. Tephra B2 is a LAF petrochemical type characterized by both abundant black glass and less abundant colorless glass, the latter with high abundances of spherical vesicles and no mineral microlites. Phenocrysts include abundant plagioclase, clinopyroxene, orthopyroxene, and small to moderate abundances of both olivine and dark brown amphiboles. Based on its LAF-type petrochemistry and the presence of both clear glass and amphibole, we suggest that its source was Mentolat volcano.

\section{Tephra group $C$}

Tephra group C generally occurs as two deposits. Tephra C1, the thicker (up to $3 \mathrm{~cm}$ ) of the two, which was sampled from four of the lake cores, is a HA chemical type which consists of both black and dark brown glasses with no or minor spherical vesicles and abundant plagioclase microlites. Phenocrysts include plagioclase along with minor pyroxenes and trace olivine. $\mathrm{C} 2$ is thinner but has similar HA chemical and petrologic characteristics. Based on their HA chemistry, both tephras are interpreted as having been derived from Hudson volcano.

\section{Tephra group D}

Tephra group D contains three distinct deposits. Tephras D1 and D2 are generally $1 \mathrm{~cm}$ or less in thickness, while tephra D3 is up to $8 \mathrm{~cm}$ in thickness. Tephra D1 is a LAF petrochemical type characterized by two distinct glass types: one is black in color with no visible vesicles and the other is clear with moderate abundances of undeformed spherical vesicles. Phenocrysts in D1 include plagioclase, minor clinopyroxene, orthopyroxene, olivine, and trace amphibole. These features together suggest that D1 tephra was derived from Mentolat.

Tephra D2 is a HA chemical type and thus likely to have been derived from Hudson volcano, although its Ti content is 
somewhat low compared to the other Hudson samples (Fig. 3). It consists of dark orange-brown glass color containing a moderate abundance of undeformed spherical vesicles and a high abundance of mineral microlites. Phenocrysts include plagioclase and clinopyroxene.

Tephra D3 is a LAM chemical type with blocky dark orange-brown to black glass containing few or no spherical vesicles and lacking microlites. This tephra contains plagioclase phenocrysts along with minor clinopyroxene and trace olivine. We correlate this tephra with the MAC1 eruption dated as 1440 cal years BP (Table 1) based on its LAM trace element chemistry and thickness, which is consistent with the $10 \mathrm{~cm}$ isopach (Fig. 1) as estimated by Naranjo and Stern (2004), and its stratigraphic position in the cores, which is consistent with an age similar to that of MAC1. We also suggest that this is equivalent to tephra T3 in Castor and Escondido lakes (Fig. S1 in the supplementary files) identified by Elbert et al. (2013), which is one of the thickest of the eight tephras they have identified, and has essentially the same bulk chemistry as MAC1 determined by Naranjo and Stern (2004). Although their bulk sediment age for this tephra (160 AD) is 500 years older than that of MAC1, Bertrand et al. (2012) have shown that lake sediment ${ }^{14} \mathrm{C}$ ages may be significantly older than true ages because of the input from the surrounding drainage basin of older organic material into a lake.

\section{Tephra group E}

Tephra group E contains up to four different deposits. Tephras $\mathrm{E} 1$ and $\mathrm{E} 4$ range in thickness only up to $1 \mathrm{~cm}$, while $\mathrm{E} 3$ is up to $2 \mathrm{~cm}$ and $\mathrm{E} 2$ up to $3 \mathrm{~cm}$ (Table 1). E4 was too thin to sample. E1 and E2 (Fig. 4) are HA chemical types, suggesting that Hudson was the source of these two tephras, although both have low Ti compared to other HA samples (Fig. 3). They consist of dark orange to pale brown glass containing moderate abundances of circular vesicles and moderate to high abundances of microlites. The dominant phenocrysts within these deposits are plagioclase, but orthopyroxene and clinopyroxene also occur.

Tephra E3 is a LAM chemical type with both black and brown glasses with no or few visible vesicles and abundant microlites. Plagioclase is the only phenocryst observed. This tephra may be sourced from either Macá or Cay or one of the MECs.

\section{Tephra group F}

Tephra group F contains three deposits, all of which are $1 \mathrm{~cm}$ or less in thickness and HA chemical types, and therefore, all are considered to be derived from Hudson volcano (Table 1). They are characterized by both black and orange-brown glasses, the latter with moderate to low abundances of weakly deformed vesicles and moderate to high abundances of microlites. Plagioclase and trace orthopyroxene occur as phenocrysts. Based on its stratigraphic position in the cores and its HA trace element character, we correlate tephra F3 with the $2235 \pm 120$ cal years BP mafic Hudson tephra T6 described by Naranjo and Stern (1998). Elbert et al. (2013) also correlate their tephra T6 (300 BC) with that described by Naranjo and Stern (2004), as both have similar age and chemistry.

\section{Tephra group $G$}

Tephra group G consists of three LAM chemical-type deposits (Table 1), suggesting that they may be sourced from either Macá or Cay or one of the MECs. We correlate G1, which is the thickest (up to $2 \mathrm{~cm}$ ), with tephra T7 (1700 BC) of Elbert et al. (2013) on the basis of its stratigraphic position just above $\mathrm{H} 2$. The glass in these three deposits is either black, with no or few visible microlites or vesicles, or brown with moderate to low abundances of spherical vesicles and abundant microlites. Phenocrysts include plagioclase and clinopyroxenes, orthopyroxene, and trace amounts of olivine.

\section{Tephra H2}

The bottom of zone I corresponds to the 8 - to $>50$-cm-thick tephra produced by the HA chemical-type Hudson $\mathrm{H} 2$ eruption at $4000 \pm 50 \mathrm{cal}$ years BP (Naranjo and Stern 1998). These are tephra T8 of Elbert et al. (2013), estimated by them as 4060 cal years BP based on an extrapolation assuming a constant sedimentation rate during the 700 years before their oldest date at $3348 \pm 100$ cal years BP, and tephra HW5 of Haberle and Lumley (1998), estimated by them as 3850 cal years BP also based on extrapolation assuming a constant sedimentation rate from after an older age of 4250 \pm 35 cal years BP from deeper in the core. It contains vesiclerich, pale orange-brown glass and phenocrysts of plagioclase and orthopyroxene.

\section{Zone II: $\mathrm{H} 2$ to top of the $\mathrm{S} 1-10$ sequence}

\section{Tephra I}

Tephra I is a HA chemical type with a broad spectrum of glass morphologies that range from dark brown mafic glass with minor microlites and few spherical vesicles to pale brown glass with moderate abundances of stretched vesicles that grade into light tan to clear glass with high abundances of stretched vesicles. Phenocrysts include minor amounts of pyroxenes and plagioclase. Based on its HA chemistry, we suggest that this tephra, which is thicker in the southern lake cores (up to $2 \mathrm{~cm}$ ), is derived from Hudson volcano. The trace element chemistry for the proximal deposit (Lago Espejo; Table S3 in the supplementary files) is overall more mafic in composition (higher $\mathrm{Ti}, \mathrm{Mn}$, and $\mathrm{Sr}$ and lower $\mathrm{Rb}, \mathrm{Ba}$, and $\mathrm{Zr}$ ) 
than the two distal deposits (Lago Élida and Lago Unco; Tables S6 and S7 in the supplementary files), and the Lago Espejo deposit contains a larger proportion of dark brown glass compared to pale brown glass. We interpret this to result from variable wind directions during its eruption such as that also occurred during the 1991 AD Hudson eruption, which distributed phase 1 basaltic tephra to the north and phase 2 trachyandesitic tephra to the southeast (Scasso et al. 1994; Kratzmann et al. 2009).

\section{Tephras $J$ and $K$}

Tephras $\mathrm{J}$ and $\mathrm{K}$ are HA chemical types, and both are up to $1 \mathrm{~cm}$ in thickness in the southern cores. Both consist predominantly of black and brown glass with minor undeformed spherical vesicles and a high abundance of microlites. Plagioclase is the dominant phenocrysts, and pyroxenes are also present in these deposits. Based on their HA-type chemistry, both tephras were derived from Hudson volcano.

\section{Tephras Ls and Ln}

Tephras Ls and Ln are two thin tephra deposits in similar stratigraphic position in the southern (Ls) and northern (Ln) lakes, but with different petrochemistry and source volcanoes. Ls is a LAM petrochemical type which contains abundant black to dark brown glass with minor undeformed spherical vesicles and microlites. Plagioclase phenocrysts occur along with trace amounts of pyroxenes. This tephra may have been sourced from either Macá or Cay or one of the MECs. Ln in contrast is a LAF petrochemical type which has clear microlite-free glass with abundant spherical vesicles. Plagioclase, pyroxenes, olivine, and abundant amphibole occur in this Ln tephra, which is similar to MEN1 tephra (Fig. 4), and we therefore suggest that it is derived from Mentolat.

\section{Tephras $M$ and $N$}

Tephras $\mathrm{M}$ and $\mathrm{N}$ are only observed in the southern lakes where they have thicknesses up to 2 and $5 \mathrm{~cm}$, respectively. Both are HA chemical types, and we therefore suggest that they are derived from Hudson volcano. They contain pale brown glass lacking microlites, but with abundant stretched vesicles similar to $\mathrm{H} 2$ glass (Fig. 4b). Phenocrysts include plagioclase, clinopyroxene, and orthopyroxene.

\section{Tephra group $O$}

Tephra $\mathrm{O} 1$ is a LAF petrochemical-type tephra deposits, containing dark vesicle-poor but microlite-rich glass along with clear glass. It contains abundant plagioclase and pyroxene phenocrysts, olivine, as well as both brown and green amphiboles and biotite, and we therefore suggest that it was derived from Mentolat volcano. Tephra $\mathrm{O} 2$ is a LAM petrochemical type which is up to $6 \mathrm{~cm}$ in thickness in the northern cores. $\mathrm{O} 2$ is characterized by black, vesicle-poor glass with a high abundance of mineral microlites. Phenocrysts include low abundances of plagioclase and clinopyroxene. This tephra may have been derived from either Macá or Cay or one of the MECs.

\section{Tephra group $P$}

Group P comprises two tephra deposits. The younger one (P1) is a LAM chemical type which is up to $5 \mathrm{~cm}$ in thickness and is characterized by abundant blocky black glass with moderate amounts of mineral microlites, few vesicles, and abundant plagioclase, along with trace amounts of pyroxenes. It was derived from either Macá or Cay or one of the MECs. The older P2 is a HA chemical type, with distinctive high Ti content (Fig. 3; Table 4), containing stretched vesicle-rich orange glass with few mineral microlites and only a small proportion of plagioclase and pyroxene phenocrysts. Based on these petrochemical characteristics, we suggest that this tephra was derived from Hudson volcano.

\section{Tephra group $Q$}

Tephra group Q consists of two LAF petrochemical-type tephra, containing both dark brown glass with spherical to moderately deformed oval vesicles and with few microlites and also clear glass with abundant circular vesicles. Phenocrysts include plagioclase, clinopyroxene, orthopyroxene, olivine, and amphibole, and we suggest that both these tephras were derived from Mentolat.

\section{Tephra MEN1}

MEN1 tephra ranges in thickness between $<1$ and $4 \mathrm{~cm}$ and is thicker in the northern lakes. It is a LAF chemical type with abundant colorless glass containing undeformed circular vesicles (Fig. 4). Plagioclase, clinopyroxene, orthopyroxene, olivine, and amphibole occur as phenocrysts. This tephra is correlated with the 7710 cal years BP MEN1 tephra (Fig. 1) observed in the outcrop west and north of Coyhaique (Naranjo and Stern 2004) as well as in cores from Lago Shaman to the northeast (Fig. 1; de Porras et al. 2012; Stern et al. 2015a), from small lakes further south near Cochrane such as Lago Augusta (Fig. 1; Villa-Martínez et al. 2012; Stern et al. 2013, 2015b), and bog cores to the southeast in Argentina (McCulloch et al. 2014).

\section{Tephra R}

This is a LAF petrochemical-type tephra, with clear and minor black glass, with plagioclase, clinopyroxene, orthopyroxene, 
olivine, amphibole, and biotite phenocrysts, which we suggest that, based on its petrochemistry, it is derived from Mentolat volcano. It is thicker to the north.

\section{Zone III: S1-S10 tephra sequence}

Zone III consists of a sequence of 10 closely spaced tephra which has been dated as between $>14,080$ and $<14$, 910 cal years BP (Fig. 7; Table S1 in the supplementary files; Miranda et al. 2013). Five of the cores contain all 10 of these clearly distinct tephra layers separated by lacustrine sediments (Espejo, Quijada, Churrasco, Élida, Unco), whereas in the other three northern lakes (Las Mellizas, El Toro, and Tranquilo), tephras S1-S5 are clearly present, but not all of S6-S10 are definitive. The thickness of each deposit in the different lakes is variable, but only by a small amount (from 3 to $<1 \mathrm{~cm}$ ).

Tephra S1-S3 and S5-S10 are all HA chemical types, which consist of mafic dark brown volcanic glass with spherical non-stretched vesicles, abundant plagioclase microlites, but few mineral phenocrysts (Fig. 4). Chemically, these nine tephras are similar to mafic magmas erupted from Hudson volcano (Table 5), either as lavas (HV-107; Gutiérrez et al. 2005), tephra such as phase 1 in the H3 event (Kratzmann et al. 2009, 2010), or the mafic components of the Late Glacial Ho eruption (Weller et al. 2014).

$\mathrm{S} 4$, in contrast, is clearly distinguishable from the other tephras by its light brown glass with abundant stretched vesicles, common plagioclase and pyroxene phenocrysts, and trace element chemistry, indicating a more felsic tephra (Table 5). The fact that the S4 tephra is morphologically and petrochemically distinct from the others establishes a definitive stratigraphic marker that allows for the correlation of the other nine S deposits. S4 tephra has glass color, morphology, and HA chemical composition characteristic of the other intermediate-to-silicic tephras derived from Hudson volcano such as $\mathrm{H} 2$.

The entire S1-S10 sequence overlaps in age the oldest 14, 560 cal years BP Hudson-derived tephra (HW1) identified from the Pacific Coast by Haberle and Lumley (1998) and tephra TL5 at $800 \mathrm{~cm}$ depth in the Pacific Ocean core MD07-3088 (Siani et al. 2010; Carel et al. 2011).

\section{Zone IV: S10 through the base of the cores}

\section{Tephra T}

Tephra $\mathrm{T}$ is a LAF petrochemical type only observed in the northern cores (Table 1). This tephra is characterized by clear glass with abundant circular vesicles. It contains phenocrysts of plagioclase, clinopyroxene, orthopyroxene, and minor amounts of weakly pleochroic brown amphibole, and for these reasons, we suggest that it was derived from Mentolat volcano.

\section{Tephra group $U$}

Tephra group $\mathrm{U}$ consists of two to three thin but well-defined deposits observed in most of the cores, none of which were sampled because they were all too thin.

\section{Tephra $V$}

Tephra $\mathrm{V}$ is observed in all of the lakes as an approximately $1-\mathrm{cm}$ deposit. It is a HA chemical type, and therefore, we suggest that it is derived from Hudson volcano. Tephra V is characterized by dark brown glass with a blocky morphology, high abundances of microlites, low abundances of undeformed vesicles, and minor plagioclase and pyroxene phenocryst.

\section{Tephras $W s$ and $W n$}

Tephras Ws and Wn are two chemically and morphologically distinct tephra deposits that occur in about the same stratigraphic position. Tephra $\mathrm{Wn}$ is up to $1 \mathrm{~cm}$ in thickness in the northern lakes, while tephra Ws is up to $2 \mathrm{~cm}$ in thickness in the southern lakes. Tephra $\mathrm{Wn}$ is a LAM chemical type containing dark brown microlite-rich glass with spherical vesicles and moderate abundances of plagioclase and minor pyroxenes phenocrysts. This tephra may have been sourced from either Macá or Cay or one of the MECs. Tephra Ws in the southern lakes is a HA chemical type, derived from Hudson volcano, with dark orange to brown microlite-rich glass and moderate amounts of plagioclase and pyroxene phenocrysts.

\section{Tephra group $X$}

Tephra group $\mathrm{X}$ generally consists of three deposits, all of which are $1 \mathrm{~cm}$ or less in thickness, although in some cores, tephra X1 is missing or very thin. All are HA chemical types, derived from Hudson volcano, with dark to pale orangebrown blocky glass containing both circular and elongated vesicles and few microlites. Plagioclase and pyroxene phenocrysts are present.

\section{Tephra group $Y$}

Tephra group Y includes two tephras. Y1 is a 1-cm or less LAM chemical-type tephra characterized by a low abundance of pale brown glass with moderate to high abundances of microlite and minor circular vesicles. It contains plagioclase and minor pyroxene phenocrysts. This tephra may have been sourced from either Macá or Cay or one of the MECs. Tephra Y2 was not sampled. 


\section{Tephra group $Z$}

Tephra group Z generally consists of five deposits. Tephra Z1 was sampled from six of the lake cores and is a HA chemical type that ranges in thickness from 2 to $9 \mathrm{~cm}$. It is characterized by pale brown blocky glass with minor microlites and vesicles that range from circular to moderately elongated. Plagioclase phenocrysts exist along with minor amounts of pyroxenes. Z1 was derived from Hudson.

Tephra Z2, or Ho (Fig. 3), described by Weller et al. (2014), was produced by a very large Late Glacial eruption from Hudson bracketed in age between 17,300 and 17,440 cal years BP. Based on its age and thickness, this corresponds to the $42-\mathrm{cm}-$ thick tephra observed by Markgraf et al. (2007) between 1109 and $1151 \mathrm{~cm}$ depth from a core in Mallín Pollux (Fig. S1 in the supplementary files).

Tephra Z3 is a LAM chemical type that is approximately 1$2 \mathrm{~cm}$ in thickness in three of the northern lakes. It is characterized by microlite-rich pale brown to orange-brown glass with few spherical vesicles and abundant plagioclase and minor pyroxene phenocrysts. Z3 was derived from either Macá or Cay or one of the MECs.

$\mathrm{Z} 4$, or MENo, is a LAF petrochemical-type tephra characterized by colorless glass that lacks microlites and contains abundant small undeformed circular vesicles. It contains abundant plagioclase and orthopyroxene phenocrysts as well as minor clinopyroxene, olivine, and dark brown amphibole. It is observed in three of the northern lakes and is derived from Mentolat volcano. It also occurs in Lago Shaman (de Porras et al. 2012; Stern et al. 2015a).

The Z5 tephra is a LAM chemical type that is approximately $1 \mathrm{~cm}$ in thickness and only occurs in two northern lake cores. It is characterized by its black irregularly shaped glass with abundant large microlites (Fig. 4) and contains abundant plagioclase phenocrysts and minor pyroxenes. Z5 was derived from either Macá or Cay or one of the MECs.

\section{Discussion and conclusion}

Some of the many dense layers observed as white bands in the $\mathrm{X}$-ray images (Fig. 2) of the multiple lake cores from near Coyhaique, Chile, may be sands or re-worked tephra, but the $>60$ tephras listed in Table 1 all occur in similar stratigraphic relations to each other in multiple cores (Figs. 5, 6, 7, and 8), and we therefore consider them to be derived from independent eruptions. The chemistry and petrology of 55 of these $>60$ tephras are consistent with and support the correlations based on stratigraphy alone. We therefore conclude that $>60$ explosive eruptions of various sizes of SSVZ volcanoes, including possibly the minor eruptive cones (MECs), have occurred since the glacial retreat at approximately 17 , 800 cal years BP.

Most of the eruptions observed in these cores must have been small $\left(<0.1 \mathrm{~km}^{3}\right)$, since they are thin (Table 1) and fine grained (Table 2). Only four of the tephras preserved in these lakes $(\mathrm{D} 3=\mathrm{MAC} 1, \mathrm{~F} 3=\mathrm{T} 6$ and $\mathrm{H} 2$ from Hudson, and MEN1) have been correlated with the tephras previously reported in outcrops in the region, and these form the thickest (Table 1) and coarsest grained (Table 2) deposits in the cores, with the exception of Ho which has not been observed in outcrop. Nevertheless, it is clear that although tephrochronology studies based solely on outcrops, such as those of Naranjo and Stern (1998, 2004), are satisfactory for identifying large eruptions, they are only seeing a minor proportion with regard to all eruptions, a conclusion also reached by Moreno et al. (2015) for Chaitén volcano further north in the SSVZ. On the other hand, it is also significant to note that
Fig. 9 Eruption volumes for volcanic centers of the SVZ between $37^{\circ}$ and $47^{\circ} \mathrm{S}$ from Late Glacial and Holocene time. Modified from Watt et al. (2013) to include the many small volume $\left(<<1 \mathrm{~km}^{3}\right)$ eruptions from Hudson, Mentolat, and either Macá or Cay or one of the MECs documented in this study and the eruptions identified by Stern et al. (2015a) in Lago Shaman and Mallín el Embudo east of the arc (Fig. 1), by Haberle and Lumley (1998) along the western coast, and by Siani et al. (2010, 2013) and Carel et al. (2011) in Pacific Ocean marine cores

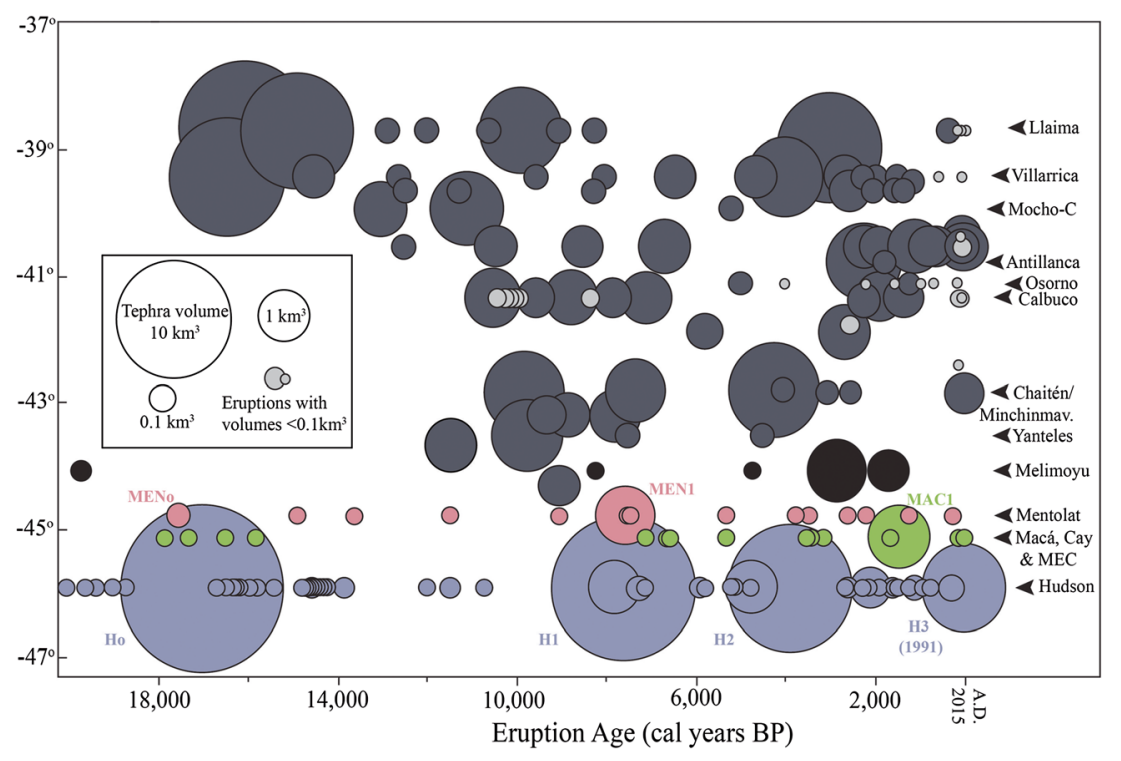


tephras from one of the largest Holocene eruptions of Hudson, the $\mathrm{H} 1$ event at $8170 \pm 60$ cal years BP, nor the more recent $\mathrm{H} 3$ (1991 phase 2) eruption (Stern 1991, 2008; Naranjo and Stern 1998; Kratzmann et al. 2009; Prieto et al. 2013; Stern et al. 2015b), do not occur in any of these cores because they were not distributed towards the northeast of the volcano (Fig. 1).

The northern lakes contain a higher proportion of tephras that are similar in morphology and chemistry to previously identified tephras derived from Mentolat (10 in total), whereas the southern lakes preserve a larger proportion of tephras chemically and petrologically similar to previously described tephras derived from Hudson (32 in total; Table 1). Thirteen tephras are considered to be derived from either Macá or Cay or MEC, with one of these correlated with tephra MAC1 from Macá. Seven tephras identified in multiple cores, and a number not correlated across cores, have not been sampled.

The majority of the analyzed deposits lay within the chemical fields defined using previously published data for the eruptive products from the SSVZ volcanic centers (Fig. 3). Three deposits petrographically similar to Hudson-derived tephras have lower Ti than other Hudson samples but are, in other ways, similar chemically to Hudson-derived rocks. Several samples that are attributed to Mentolat volcano also lie within the Macá, Cay, or MEC fields, with higher Ti at a given $\mathrm{Rb}$ content than Mentolat lavas, but these tephras contain clear volcanic glass and brown amphibole, similar to the volcanic products from the previously documented MEN1 eruption (Naranjo and Stern 2004; Stern et al. 2015a, b). They also contain mafic components such as microlite-rich and vesicle-poor dark mafic volcanic glass and olivine. These different glass components likely represent different phases of the eruptions similar to the range in tephra chemistry and petrology observed in outcrops of the MEN1 eruption (Naranjo and Stern 2004) and in the products of other chemically heterogeneous SSVZ explosive eruptions.

The large number of eruptions documented from the lake cores near Coyhaique represents a significant contribution to the record of eruptions from volcanoes in this region during Late Glacial and Holocene times (Fig. 9). These new results indicate that although explosive eruptions within the SSVZ are episodic, they have, on average, been regularly repetitive throughout Late Glacial to historic times without any significant change in the frequency. This conclusion extends back to 20,000 cal years BP, before the Last Glacial Maximum, when the tephras from Pacific Ocean marine cores are also considered (Carel et al. 2011), and suggests that deglaciation did not enhance the rates of explosive eruptions.

The new information, combined with previously published data concerning tephras derived from Hudson volcano (Naranjo and Stern 1998; Haberle and Lumley 1998; Carel et al. 2011; Weller et al. 2014), indicates that this volcano has had $>55$ explosive eruptions since 20,000 cal years BP (Fig. 9). These eruptions have produced $>45 \mathrm{~km}^{3}$ of pyroclastic material based on previously published volume estimates of its larger eruptions (Weller et al. 2014). This makes Hudson one of the most active volcanoes in the SSVZ in terms of both frequency and volume of explosive eruptions, comparable to Volcán Mocho-Choshuenco (Rawson et al. 2015), perhaps as a result of its location just east of the Chile Rise-Trench triple junction. Nevertheless, the tephra record indicates that local population centers such as Coyhaique (Fig. 1) could also be profoundly affected by future eruptions from Macá and Mentolat volcanoes similar in magnitude to those that occurred in the past.

Using the radiocarbon ages of the S1-10 tephra (Fig. 7; Miranda et al. 2013) and of previously dated eruptions (MAC1; H2, MEN1; Ho; Naranjo and Stern 2004; Weller

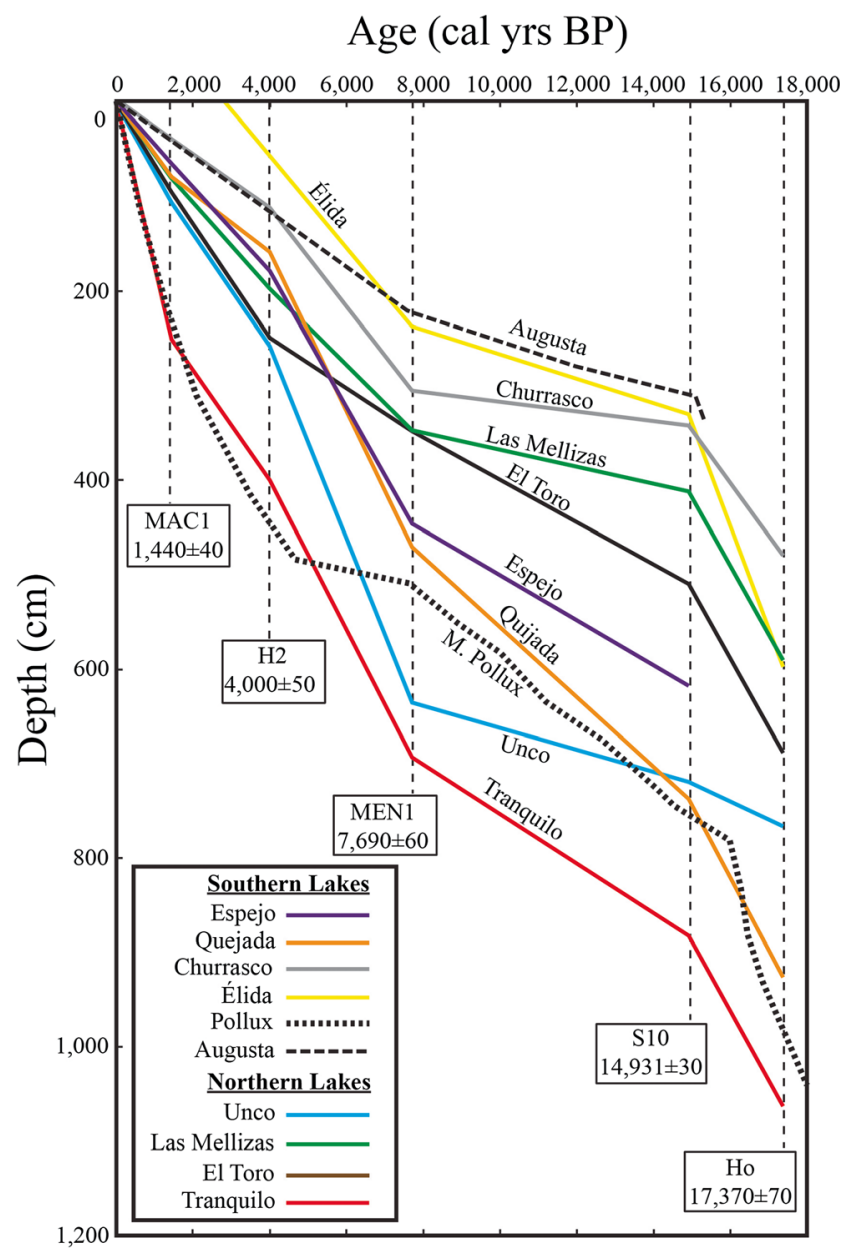

Fig. 10 Sedimentation profiles for the eight lake cores, from the surface to the top of the Ho tephra, using the ages of previously dated large explosive eruptions from Hudson $(\mathrm{H} 2, \mathrm{Ho})$, Mentolat $(\mathrm{MEN} 1)$, and Macá (MAC1) (Table 1; Naranjo and Stern 1998, 2004; Weller et al. 2014), including two previously published profiles, based on independent sets of internal age dates, from Mallín Pollux (Markgraf et al. 2007) and Lago Augusta (Villa-Martínez et al. 2012). The thickness of the $\mathrm{H} 2$ tephra, which ranges from 8 to $53 \mathrm{~cm}$ (Table 1), has been subtracted from the total integrated length of the sediment in the cores, but other tephra layers, which are about of the same thickness in every core, have not 
et al. 2014; Stern et al. 2015b), the depth versus age sedimentation profiles for the eight lake cores are compared to each other and to profiles from other lakes in the region (Fig. 10), including Mallín Pollux (Markgraf et al. 2007) and Augusta (Fig. 1; Villa-Martínez et al. 2012). The profiles all exhibit intervals of both slower and more rapid accumulations of material within the lakes. Significantly, the cores show similar patterns, with relatively rapid sedimentation rates between 18 , 000 and 15,000 cal years BP, followed by slower rates up to 7500 cal years BP, after which relatively more rapid sedimentation rates prevail. A similar conclusion was reached previously for Lago Augusta (Villa-Martínez et al. 2012) and Mallín Pollux (Markgraf et al. 2007) based on a greater number of internally consistent age dates. However, significantly different explanations, involving changes in precipitation and temperature, have been proposed to explain these changes in these two lakes. Resolving these differences, which require other data such as identification of pollen types at different depths in the cores, is beyond the scope of this paper. Nevertheless, the profiles illustrate the power of tephrochronology for constraining temporal correlations among core records over a relatively large region, and the data suggest that these changes in sedimentation rates were produced by regional environmental changes that affected the lakes located both in the semiarid region to the east of the current drainage divide (Unco and Élida) as well as in the wetter region more to the west (Espejo).

Acknowledgments We thank M. Kaplan, M. Fletcher, I. Vilanova, W. Henriquez, and E. Simi for their assistance in the field in obtaining the cores. This research was supported by Fondecyt (Chile) grant no. 1121141, the Institute of Ecology and Biodiversity grants ICM P05-002 and PFB-23, and the Department of Geological Sciences, CU-Boulder. We would also like to thank the Nightingale and Weller families for their continued support. S. Watt, S. Kuehn, and an unidentified reviewer provide many helpful comments on an early version of this manuscript.

\section{References}

Bertrand S, Araneda A, Vargas P, Jana P, Fagel N, Urrutia R (2012) Using the N/C ratio to correct bulk radiocarbon ages from lake sediments: insights from Chilean Patagonia. Quat Geochron 12:23-29

Bertrand S, Daga R, Bedert R, Fontijn K (2014) Deposition of the 20112012 Cordon Caulle tephra (Chile, $40^{\circ} \mathrm{S}$ ) in lake sediments: implications for tephrochronology and volcanology. J Geophys Res 119: 2555-2573

Best JL (1992) Sedimentology and event timing of a catastrophic volcaniclastic mass flow, Volcán Hudson, Southern Chile. Bull Volcanol 54:299-318

Björck S, Rundgren M, Ljung K, Unkel I, Wallin A (2012) Multi-proxy analyses of a peat bog on Isla de los Estados, easternmost Tierra del Fuego: a unique record of the variable Southern Hemisphere Westerlies since the last deglaciation. Quat Sci Rev 42:1-14

Cande SC, Leslie RB (1986) Late Cenozoic tectonics of the Southern Chile Trench. J Geophys Res 91(B1):471-496
Carel M, Siani G, Delpech G (2011) Tephrostratigraphy of a deep-sea sediment sequence off the south Chilean margin: new insight into the Hudson volcanic activity since the last glacial period. J Volcanol Geotherm Res 208:99-111

Cembrano J, Hervé F, Lavenu A (1996) The Liquiñe-Ofqui Fault Zone: long-lived intra-arc fault system in Southern Chile. Tectonophys 259:55-66

D’Orazio M, Innocenti F, Manetti P, Tamponi M, Tonarini S, GonzálezFerrán O, Lahsen A (2003) The Quaternary calc-alkaline volcanism of the Patagonian Andes close to the Chile triple junction: geochemistry and petrogenesis of volcanic rocks from the Cay and Maca volcanoes ( $45^{\circ} \mathrm{S}$, Chile). J S Amer Earth Sci 16(4):219-242

de Porras ME, Maldonado A, Abarzúa AM, Cárdenas ML, Francois JP, Martel-Cea A, Stern CR (2012) Postglacial vegetation, fire and climate dynamics at Central Chilean Patagonia (Lake Shaman, $44^{\circ} \mathrm{S}$ ). Quat Sci Revs 50:71-85

de Porras ME, Maldonado A, Quintana FA, Martel-Cea JO, Reyes O, Méndez C (2014) Environmental and climatic changes in Central Chilean Patagonia since the Late Glacial (Mallín El Embudo, 44으). Climates of the Past 10:1063-1078

Elbert J, Wartenburg R, von Gunten L, Urrutia R, Fisher D, Fujak M, Hamann Y, Greber ND, Grosjean M (2013) Late Holocene air temperature variability reconstructed from the sediments of Laguna Escondida, Patagonia Chile. Palaeogeog Palaeoclimat Palaeoecol 396:482-492

Fontijn K, Lachowycz SM, Rawson H, Pyle DM, Mather TA, Naranjo JA, Moreno-Roa H (2014) Late Quaternary tephrostratigraphy of Southern Chile and Argentina. Quat Sci Revs 89:70-84

Futa K, Stern CR (1988) Sr and Nd isotopic and trace element compositions of Quaternary volcanic centers of the Southern Andes. Earth Planet Sci Lett 88:253-262

Gonzáles-Ferrán O (1994) Volcanes de Chile. Instituto Geografico Militar, Santiago, 640 p

Gutiérrez F, Gioncada A, González-Ferrán O, Lahsen A, Mazzuoli R (2005) The Hudson volcano and surrounding monogenetic centres (Chilean Patagonia): an example of volcanism associated with ridgetrench collision environment. J Volcanol Geotherm Res 145:207233

Haberle SG, Lumley SH (1998) Age and origin of tephras recorded in postglacial lake sediments to the west of the Southern Andes, $44^{\circ} \mathrm{S}$ to $47^{\circ} \mathrm{S}$. J Volcanol Geotherm Res 84:238-256

Kratzmann DJ, Carey S, Scasso RA, Naranjo JA (2009) Compositional variations and magma mixing in the 1991 eruptions of Hudson volcano, Chile. Bull Volcanol 71(4):419-439

Kratzmann DJ, Carey S, Scasso RA, Naranjo JA (2010) Role of cryptic amphibole crystallization in magma differentiation at Hudson volcano, Southern Volcanic Zone, Chile. Contrib Mineral Petrol 159: 237-264

López-Escobar L, Kilian R, Kempton P, Tagiri M (1993) Petrology and geochemistry of Quaternary rocks from the southern volcanic zone of the Andes between $41^{\circ} 30^{\prime}$ and $46^{\circ} 00^{\prime} \mathrm{S}$, Chile. Rev Geol Chile 20:33-55

López-Escobar L, Parada MA, Hickey-Vargas R, Frey FA, Kempton P, Moreno H (1995) Calbuco volcano and minor eruptive centers distributed along the Liquiñe-Ofqui Fault Zone, Chile $\left(41^{\circ} \mathrm{S}\right)$ contrasting origin of andesitic and basaltic magma in the Southern Volcanic Zone of the Andes. Contr Mineral Petrol 119:345-361

Lowe DJ (2011) Tephrochronology and its application: a review. Quat Geol 6:107-153

Markgraf V, Whitlock C, Haberle S (2007) Vegetation and fire history during the last 18,000 cal yr B.P. in Southern Patagonia: Mallín Pollux, Coyhaique, Province Aisén $\left(45^{\circ} 41^{\prime} 30^{\prime \prime}, 71^{\circ} 50^{\prime} 30^{\prime \prime} \mathrm{W}, 640\right.$ m elevation). Palaeogeogr Palaeoclimatol Palaeoecol 254:492-507

McCulloch R, Figuerero MJ, Mengoni GL, Barclay R (2014) Un registro Holoceníco de cambios ambientales dinamicos y cronología cultural de Monte Zeballos-Paso Roballos, Santa Cruz, Patagonia central. 
Libro de Resumenes, IX Jornadas de Arqueología de la Patagonia, Coyhaique, $\mathrm{p} 4$

Mella M, Ramos A, Kraus S, Duhart P (2012) Tefroestratigrafía, magnitud y geoquímica de erupciones holocenas mayores del volcán Mentolat, Andes del Sur (4440'S), Chile. Actas, Congreso Geológico Chileno, No. 13, Antofagasta

Miranda CG, Moreno PI, Vilanova I, Villa-Martínez RP (2013) Glacial fluctuations in the Coyhaique-Balmaceda sector of central Patagonia $\left(45^{\circ} \mathrm{S}-46^{\circ} \mathrm{S}\right)$ during the last glacial termination. Bollettino di Geofisica 54:268-271

Moreno P, Alloway BV, Villarosa G, Outes V, Henríquez WI, De PolHolz R, Pearce NJG (2015) A past-millennium maximum in postglacial activity from Volcán Chaitén, Southern Chile. Geology 43: $47-50$

Naranjo JA (1991) Nueva erupción del volcán Hudson. Rev Geol Chile 18:183-184

Naranjo JA, Stern CR (1998) Holocene explosive activity of Hudson volcano, Southern Andes. Bull Volcanol 59(4):291-306

Naranjo JA, Stern CR (2004) Holocene tephrochronology of the southernmost part $\left(42^{\circ} 30^{\prime}-45^{\circ} \mathrm{S}\right)$ of the Andean Southern Volcanic Zone. Rev Geol Chile 31(2):225-240

Nelson E, Forsythe R, Arit I (1994) Ridge collision tectonics in terrane development. J S Amer Earth Sci 7(3-4):271-278

Orihashi Y, Naranjo JA, Motoki A, Sumino H, Hirata D, Anma R, Nago K (2004) Quaternary volcanic activity of Hudson and Lautaro volcanoes, Chilean Patagonia: new constraints from K-Ar ages. Rev Geol Chile 31:207-224

Prieto A, Stern CR, Esterves J (2013) The peopling of the FuegoPatagonian fjords by littoral hunter-gatherers after the midHolocene H1 eruption of Hudson volcano. Quat Internat 317:3-13

Rawson H, Naranjo JA, Smith V, Fontijn K, Pyle DM, Mather TA, Moreno H (2015) The frequency and magnitude of post-glacial explosive eruptions at Volcán Mocho-Choshuenco, Southern Chile. J Volcanol Geotherm Res 299:103-129

Saadat S, Stern CR (2011) Petrochemistry and genesis of olivine basalts from small monogenetic parasitic cones of Bazman stratovolcano, Makran arc, southeastern Iran. Lithos 125:609-617

Scasso RA, Corbella H, Tiberi P (1994) Sedimentological analysis of the tephra from the 12-15 August 1991 eruption of Hudson volcano. Bull Volcanol 56:121-132

Sellés D, Rodríguez AC, Dungan MA, Naranjo JA, Gardeweg M (2004) Geochemistry of Nevado de Longaví $\left(36.2^{\circ} \mathrm{S}\right)$ : a compositionally atypical volcano in the Southern Volcanic Zone of the Andes. Rev Geol Chile 31(2):293-315

Siani G, Colin C, Mechel E, Carel M, Richter T, Kissel C, Dewilde F (2010) Late glacial to Holocene terrigenous sediment record in the Northern Patagonian margin: paleoclimate implications. Palaeogeogr Palaeoclimatol Palaeoecol 297:26-36

Siani G, Michel E, De Pol-Holz R, DeVries T, Lamy F, Carel M, Isguder G, Dewilde F, Lourantou A (2013) Carbon isotope records reveal precise timing of enhanced Southern Ocean upwelling during the last deglaciation. Nat Commun 4:2758. doi:10.1038/ncomms3758

Stern CR (1991) Mid-Holocene tephra on Tierra del Fuego (54º $)$ derived from the Hudson volcano $\left(46^{\circ} \mathrm{S}\right)$ : evidence for a large explosive eruption. Rev Geol Chile 18:139-146
Stern CR (2004) Active Andean volcanism: its geologic and tectonic setting. Rev Geol Chile 31(2):161-206

Stern CR (2008) Holocene tephrochronology record of large explosive eruptions in the southernmost Patagonian Andes. Bull Volcanol 70(4):435-454

Stern CR, Kilian R (1996) Role of the subducted slab, mantle wedge and continental crust in the generation of adakites from the Andean austral volcanic zone. Contrib Mineral Petrol 123:263-281

Stern CR, Moreno PI, Henrique WI, Villa-Martinez RP, Sagredo E, Aravena JC (2013) Tephrochronology in the area around Cochrane, Southern Chile. Bollettino di Geofisica 54:199-202

Stern CR, de Porras ME, Maldonado A (2015a) Tephrochronology of the upper Río Cisnes valley ( $\left.44^{\circ} \mathrm{S}\right)$, Southern Chile. Andean Geol 42(2): 173-192

Stern CR, Moreno PI, Henrique WI, Villa-Martinez RP, Sagredo E, Aravena JC, De Pol-Holz R (2015b) Holocene tephrochronology in the area around Cochrane, Southern Chile. Andean Geol 43(1) in press

Stuiver M, Reimer PJ, Braziunas TF (1998) High-precision radiocarbon age calibration for terrestrial and marine samples. Radiocarbon 40(3):1127-1151

Unkel I, Fernandez M, Björck S, Ljung K, Wohlfarth B (2010) Records of environmental changes during the Holocene from Isla de los Estados $\left(54.4^{\circ} \mathrm{S}\right)$, southern Tierra del Fuego. Global Planet Change 74:99 113

Vargas G, Rebolledo S, Sepúlveda SA, Lahsen A, Thiele R, Townley B, Padilla C, Rauld R, Herrera MJ, Lara M (2013) Submarine earthquake rupture, active faulting and volcanism along the major Liquiñe-Ofque Fault Zone and implications for seismic hazard assessment in the Patagonian Andes. Andean Geol 40:141-171

Villa-Martínez R, Moreno PI, Valenzuela MA (2012) Deglacial and postglacial vegetation changes on the eastern slopes of the central Patagonian Andes (47ㅇ). Quat Sci Rev 32:86-99

Völker D, Kutterolf S, Wehrmann H (2011) Comparative mass balance of volcanic edifices at the southern volcanic zone of the Andes between $33^{\circ} \mathrm{S}$ and $46^{\circ} \mathrm{S}$. J Volcanol Geotherm Res 205:114-129

Watt SFL, Pyle DM, Mather TA (2011) Geology, petrology and geochemistry of the dome complex of Huequi volcano, Southern Chile. Andean Geol 38(2):335-348

Watt SFL, Pyle DM, Mather TA (2013) The volcanic response to deglaciation: evidence from glaciated arcs and a reassessment of global eruption records. Earth Sci Rev 122:77-102

Weller DJ, Miranda CG, Moreno PI, Villa-Martínez RP, Stern CR (2014) A large late-glacial Ho eruption for the Hudson volcano, Southern Chile. Bull Volcanol 76:831-849

Wilson TM, Cole JW, Stewart C, Cronin SJ, Johnston DM (2011) Ash storms: impacts of wind-remobilised volcanic ash on rural communities and agriculture following the 1991 Hudson eruption, southern Patagonia, Chile. Bull Volcanol 73:223-239

Wilson T, Cole J, Johnston D, Cronin S, Stewart C, Dantas A (2012) Short- and long-term evacuation of people and livestock during a volcanic crisis: lessons from the 1991 eruption of Volcán Hudson, Chile. J Applied Volcanol 1:2 